\title{
O komunikacji twarzą w twarz w perspektywie somatycznej
}

\author{
Wojciech Laskowski \\ INSTYTUT JĘZYKOZNAWSTWA, UNIWERSYTET IM. ADAMA MICKIEWICZA \\ AL. NIEPODLEGLOŚCI 4, 61-874 POZNAŃ \\ komunikolog@gmail.com
}

\begin{abstract}
The aim of the article is to present research and theories, which explain why nonverbal behavior, and especially body language, plays the crucial role in regulating communication among people. Firstly, research area will be outlined. An overview of face-to-face communication as a central domain of research in communication studies will be proposed. Secondly, the paper presents the main thesis in human science and in communication studies in particular. According to these thesis body is the main factor of communication process and thus, should be placed in center of the communication research. It means that body regulates what people are intending, feeling, thinking and saying during interaction with other people. It is actually an reversion of verbo-centric approach, which was the most popular and still used in linguistic approach to communication. In order to organize the body-oriented approach, two conceptions will be proposed: sign-symptom distinction and two-channel communication model. The conclusion of this paper is that science of communictation enters a new phase which could be called somatic paradigm.
\end{abstract}

\section{Komunikacja międzyludzka jako centralny temat badań nad komunikacją}

Wśród licznych typów interakcji, komunikacja twarzą w twarz² jest najbardziej naturalną, pierwotną formą kontaktów międzyludzkich. Można powiedzieć, że w domenie badań nad komunikacją - komunikacja

1 Chciałbym podziękować prof. Maciejowi Karpińskiemu za nieocenione uwagi merytoryczne i formalne, dr. Konradowi Juszczykowi za liczne konstruktywne rozmowy w trakcie redagowania niniejszego artykułu, a także mgr Katarzynie Marszałek-Kowalewskiej za inspirującą dyskusję i uwagi formalne.

${ }^{2} \mathrm{~W}$ niniejszym artykule będą zamiennie stosowane terminy „komunikacja twarzą w twarz“ i „komunikacja bezpośrednia“. 
bezpośrednia jest prototypowa, natomiast komunikacja za pomocą takich mediów, jak pismo, telefon czy Internet oraz komunikacja masowa stanowią rozszerzenia (przekształcenia) i są peryferyjnymi (zob. rys. 1).

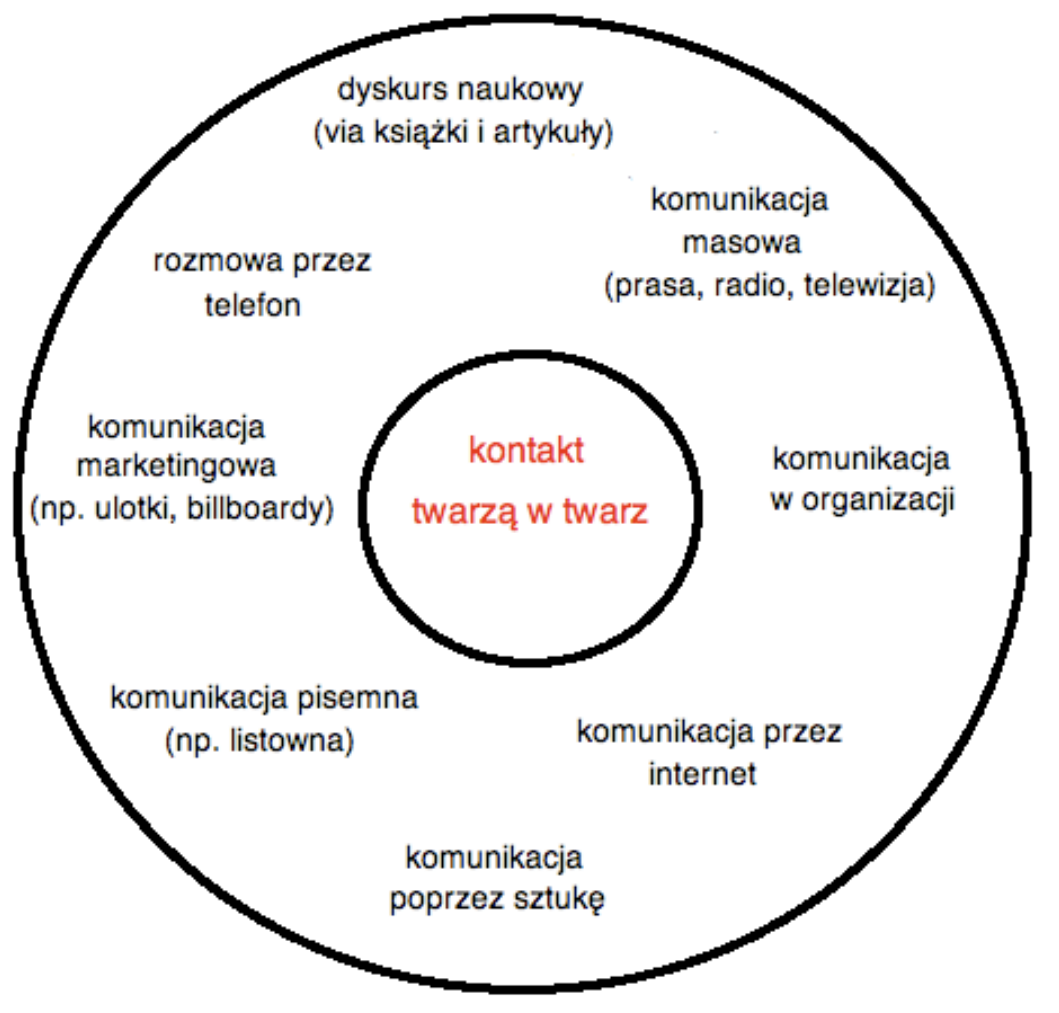

Rys. 1. Obszar badań nad komunikacja

Przekonanie takie wyraża wielu badaczy komunikacji. Przykładowo Kurcz stwierdza, że rozmowa dwu lub więcej osób jest podstawowym wzorcem realizacji kompetencji komunikacyjnej, wszystkie inne się od niej wywodzq (Kurcz 2000:138). Podobnie pisze Nęcki: Rozmowa jest najbardziej podstawowym sposobem komunikowania się ludzi (Nęcki 2000:121). Również Załazińska charakteryzuje dialog (rozmowę) jako pierwotną i najbardziej podstawową formę porozumiewania się ludzi (Załazińska 2006:7 i 11). Ważne jest przy tym, by uświadomić sobie, że komunikacja twarzą w twarz - spotkanie dwojga (lub więcej) ludzi - nie wymaga interakcji werbalnej. Wymowne milczenie, porozumiewawcze spojrzenia, gest przywoływania ręką lub głową, dotyk - wszystko to pozwala przyjąć, że choć język często wypełnia (a nawet przepełnia) przestrzeń komunikacyjną, to czasem jednak jedynie w niej „gości”. W celu zrozumienia różnicy i roli kodów werbalnego i niewerbalnego warto wstępnie wyróżnić trzy możliwe podstawowe tryby komunikacji:

$>$ (1) gdy w procesie porozumiewania się obecne są i słowa i język ciała,

$>$ (2) gdy ludzie porozumiewają się jedynie za pomocą słów, 
(3) gdy ludzie rezygnują ze słów i utrzymują kontakt jedynie niewerbalny.

Abstrahując od sytuacji (1), która jest najbardziej typowa, a jednocześnie najbardziej złożona, zastanówmy się nad tym, co różni komunikację stricte językową (pozbawioną przekazów niewerbalnych) od komunikacji czysto niewerbalnej (pozbawionej przekazów werbalnych).

Z sytuacją (2) mamy do czynienia, gdy porozumiewamy się z innymi pisemnie, np. przez Internet. Doświadczenie rozmowy za pośrednictwem komunikatora internetowego pokazuje przede wszystkim, że słowa „zachęcają" do odnoszenia się do świata faktów, świata wspólnych doświadczeń, a także do świata wewnętrznych wyobrażeń i myśli. Natomiast w chwili wkraczania na teren subiektywnych doznań i uczuć zaczyna doskwierać brak kontaktu bezpośredniego z rozmówcą. Można przypuszczać, że rozmowy bardziej osobiste niż rzeczowe skłaniają ludzi do rezygnowania $\mathrm{z}$ komunikacji pośredniej na rzecz bezpośredniego kontaktu twarzą w twarz. Mehrabian (1971) zauważa, że wybór pośrednika w postaci różnego rodzaju mediów (list, telefon itd.) wyraża stopień bezpośredniości (bliskości) między nadawcą a odbiorcą. Dodatkowo interakcja słowna stymuluje wyobraźnię, gdyż prowokuje rozmówców do wyobrażania sobie tego, jak zostali odebrani oraz tego, do czego konkretnie odnosi się interlokutor (komunikacja pisemna pozbawiona jest wspólnego kontekstu percepcyjnego). A zatem można stwierdzić, że słowo bazuje na procesach poznawczych i stymuluje je, natomiast jego rola w przekazie stanów afektywnych jest zdecydowanie mniejsza3. Etolog Sverre Sjölander ujmuje to podobnie:

Pierwszorzędna funkcja języka polega na komunikowaniu tego, czego nie ma tu i teraz (...). Oczywiście, jeżeli żyje się w teraźniejszości, a komunikacja z innymi dotyczy tylko bieżących emocji i pragnień, to wrodzone różnym gatunkom sygnały biologiczne są zupełnie wystarczające. Język potrzebny jest jedynie do komunikowania wewnętrznych reprezentacji tego, co może się stać lub co już się stało, oraz rzeczy i wydarzeń nieobecnych w otoczeniu (za: Gärdenfors 2010:208).

Podsumowując, język odrywa, dystansuje nas - od chwili obecnej (pozwala przekraczać czas i przestrzeń), od tu i teraz, od realnego świata zewnętrznego oraz świata wrażeń i emocji, za to przenosi nas w świat wewnętrzny rozumiany przede wszystkim jako świat myśli.

Trzeci przypadek, występujący prawdopodobnie najrzadziej, to momenty milczenia w trakcie komunikacji bezpośredniej, gdy dwoje ludzi z jakichś powodów decyduje się zrezygnować $\mathrm{z}$ używania języka.

3 Wymowne jest to, że $\mathrm{w}$ komunikacji pisemnej bardzo chętnie stosuje się emotikony. Świadczyć to może o tym, że interlokutorzy chcą uczynić interakcję bardziej osobistą i nieformalną albo (i) że uważają ekspresje mimiczne za bardziej przydatne w wyrażaniu stanów uczuciowych. 
Językoznawcy zidentyfikowali różne funkcje ciszy w trakcie rozmowy. Oto najważniejsze $\mathrm{z}$ nich: potwierdzenie, zaprzeczenie, ukrycie informacji, zaznaczenie interpersonalnej bliskości lub dystansu, przewagi jednego z dyskutantów, podkreślenie tego, co się dopiero powie (Jaworski 2006). Wszystkie te funkcje związane są przede wszystkim $\mathrm{z}$ aspektem relacyjnym w komunikacji, czyli $\mathrm{z}$ ustosunkowaniem mówiącego (a właściwie milczącego) do rozmówcy, do siebie samego i do tego, o czym jest mowa.

Pewnego obrazu sytuacji komunikowania bez słów dostarczają psychoterapeuci. Tacy terapeuci, jak Eichelberger, Gendlin, Rosenberg czy Boadella podkreślają, że cisza jest niezbędna, by wejrzeć we własne wnętrze, spotkać się z samym sobą. Przykładowo Eichelberger pisze:

(...) jeśli przestaniesz gadać, pojawia się szansa, że głębiej odczujesz swoje emocje, a w konsekwencji zechcesz nawiązać prawdziwy i bliski kontakt $\mathrm{z}$ ludźmi (...). Bliskość i otwartość z drugim człowiekiem wymaga bliskości i otwartości z samym sobą (Eichelberger 1999:99).

Charakterystyczne dla takiego kontaktu jest wolniejsze tempo mówienia i częste momenty milczenia. Gendlin (1981), referując przypadki, w których jego pacjenci uzyskiwali wgląd w swoje życie uczuciowe, podkreśla, że niezmiennie następowało to w ciszy, czy raczej po krótkim okresie milczenia, czemu towarzyszyło westchnienie, świadczące o odczuwanej uldze. Rosenberg (2003) z kolei, omawiając rolę empatii w komunikacji, podkreśla, że jest ona bardziej związana z obecnością niż robieniem czegoś (np. radzeniem). Psychoterapeuci somatyczni idą jeszcze dalej, wskazują bowiem na rolę ciała w komunikowaniu stanów wewnętrznych. A zatem w chwilach ciszy świadomie obserwują (nie tylko słuchają). Boadella (1992) określa ten rodzaj pracy „stawianiem czoła” i wyjaśnia, że ciało w trakcie rozmowy wysyła nieocenione wskazówki dotyczące przeżywanych przez pacjenta emocji odnoszących się do omawianych kwestii. I wyjaśnia, że do odkrycia różnych mechanizmów cielesnych (tzw. zbroi mięśniowej, bloków oddechowych itp.) doprowadziła Reicha4 ${ }^{4}$ staranna praca nad stawianiem ludzi twarza $\mathrm{w}$ twarz $\mathrm{z}$ tym, co $\mathrm{w}$ nich widział. Wyłania się z tych uwag wizja pogłębionej komunikacji, która w swej realnej postaci przepełniona jest momentami ciszy. Rozważania wymienionych terapeutów można podsumować następującym zdaniem: tylko w takich sytuacjach, gdy obecna jest cisza, możliwe jest dogłębnes poznanie i zrozumienie siebie i drugiego człowieka, a w efekcie uzyskanie prawdziwego kontaktu między interlokutorami.

\footnotetext{
4 Wilhelm Reich uważany jest za ojca psychoterapii somatycznej. Na jego prace powołują się wszyscy czołowi przedstawiciele tego nurtu terapii - Lowen, Boadella, Boysen, Marcher i inni.

5 Dogłębne - tj. odnoszące się do tego, co stoi za przedstawianymi faktami i myślami, czyli emocji, motywacji, intencji.
} 
Z powyższych analiz można wstępnie wyprowadzić następujący wniosek: komunikacja językowa służy przede wszystkim komunikowaniu stanów rzeczy niezależnych od nadawcy i odbiorcy, natomiast komunikacja niewerbalna służy przede wszystkim wyrażaniu tego, co się dzieje z mówiącymi ${ }^{6}$. Wnioski te ilustruje tabela 1.

Tabela 1. Różnice między mowq a milczeniem $w$ kontakcie twarzq w twarz.

\begin{tabular}{|l|c|c|}
\hline & Mowa & Milczenie \\
\hline Wyeksponowane & słowo & ciało \\
\hline Informacja & allocentryczna & egocentryczna \\
\hline Świat (dziedzina) & myśli i wyobrażeń & emocji i uczuć \\
\hline $\begin{array}{l}\text { Czas } \\
\text { (odniesienie) }\end{array}$ & $\begin{array}{c}\text { przeszłość i przyszłość } \\
\text { (cały czas - panchronia) }\end{array}$ & $\begin{array}{c}\text { teraźniejszość } \\
\text { (bieżąca chwila) }\end{array}$ \\
\hline
\end{tabular}

\section{Przegląd wątków badawczych w badaniach nad komunikacją międzyludzką}

Komunikacja interpersonalna to szereg różnych form porozumiewania się: przekonywanie i polemizowanie, negocjowanie, plotkowanie, manipulowanie, hipnotyzowanie, sprzedawanie produktów i usług, to również „sprzedawanie” siebie i swoich idei, ustawianie relacji (ich definiowanie, negowanie, redefiniowanie $\mathrm{i}$ podtrzymywanie), to pogawędki, w których treść nie ma większego znaczenia, to również trudne rozmowy na temat problemów osobistych, żartowanie, opowiadanie dowcipów, parodiowanie, zacięte walki na słowa, ripostowanie, flirtowanie i uwodzenie, itp. A zatem w spotkaniu dwojga ludzi można odnaleźć wiele procesów, które mogą wydawać się banalne (small talk - z ang. pogawędka), niepoważne (różne formy humoru sytuacyjnego, spontanicznego i konwersacyjnego), trudne do zbadania (uwodzenie, hipnotyzowanie, tzw. urok osobisty, zachowania charyzmatyczne). Wszystkie jednak one wyznaczają zakres badań nad komunikacją twarzą w twarz. Zanim więc przejdziemy do omówienia wyników badań wspierających tezę o kluczowej roli komunikacji niewerbalnej i języka ciała w komunikacji międzyludzkiej, najpierw podjęta zostanie próba nakreślenia (chociaż szkicowego) granic obszaru badawczego oraz jego uporządkowania. Warto $\mathrm{w}$ tym celu $\mathrm{w}$ pierwszej kolejności prześledzić wybór tematów, na omówienie których zdecydowali się autorzy czterech popularnych polskich podręczników akademickich poświęconych komunikacji interpersonalnej:

1. Podręcznik Tokarza „Argumentacja-Perswazja-Manipulacja” (Tokarz 2006), poświęcony teorii komunikacji, którego, jak zaznacza autor,

${ }^{6}$ Por. Juszczyk (2008) zestawił komunikację wirtualną i naturalną. Zob. również Skudrzyk (2005) porównała wypowiedź mówioną i pisaną, a także kod werbalny i kod wizualny (Skudrzyk 2005:75-120). 
głównym przedmiotem jest komunikacja interpersonalna (indywidualna, bezpośrednia, międzyludzka), wyróżnia zasadniczo tylko jeden wymiar tejże komunikacji. Przyjmując retoryczną perspektywę, autor wyróżnia perswazyjną funkcję komunikacji, a następnie omawia przede wszystkim takie zagadnienia, jak wnioskowanie, argumentacja, dyskutowanie, perswazja, manipulacja, kłamstwo.

2. John Stewart (2007) omawia zwłaszcza takie zagadnienia, jak przyjaźń, komunikacja $\mathrm{w}$ rodzinie, $\mathrm{w}$ relacjach damsko-męskich, w kontakcie z obcymi, w konflikcie.

3. Zbigniew Nęcki (2000) w podręczniku „Komunikacja międzyludzka” omawia zagadnienie konwersacji, klasyfikacje aktów komunikacyjnych, barier komunikacyjnych, komunikację damsko-męską.

4. Autorzy poradnika „Sztuka skutecznego porozumiewania się” (McKay, Davis i Fanning 2001) omawiają następujące tematy: kłótnia, negocjacje, komunikacja w sytuacjach towarzyskich, porozumiewanie się w rodzinie, wywieranie wpływu na ludzi, rozmowa-wywiad.

Pojawia się więc pytanie, jak ten obszar badawczy usystematyzować. Korzystając z kwadratowego modelu komunikacji Schulza von Thun (2007a), można podzielić problematykę komunikologiczną na cztery główne obszary:

1. Zagadnienia odnoszące się do poziomu rzeczowego komunikacji: zrozumiałość, rzeczowość, rozwiązywanie problemów, dialog zadaniowy, bariery komunikacyjne itp.

2. Zagadnienia odnoszące się do poziomu ujawniania siebie: autoprezentacja, autentyczność, wizerunek lidera, uwodzenie, charyzma, asertywność, radzenie sobie ze stresem itp.

3. Zagadnienia odnoszące się do poziomu wzajemnych relacji: ustawianie relacji, nawiązywanie kontaktu, uwodzenie, kłótnia, pragmatyka językowa (uprzejmość, takt, zachowania rytualne) itp.

4. Zagadnienia odnoszące się do poziomu wpływu: perswazja, manipulacja, szantaż emocjonalny, sprzedaż, negocjacje itp.

Istnieje obecnie powszechna zgoda, iż komunikacja ma charakter interakcyjny (Stewart 2007, Nęcki 2000, Załazińska 2006). Od czasu pragmalingwistów Grice'a, Austina i Searle’a (zob. Kurcz 2000) kontakty językowe ujmowane są $w$ paradygmacie prakseologicznym: język to działanie, komunikacja (konwersacja) to współdziałanie. W tym miejscu warto przypomnieć podział Kotarbińskiego na dwa rodzaje kooperacji (Kotarbiński 2000:61-63):

$>$ kooperacja pozytywna - jak w przypadku budowania relacji interpersonalnej, dostrajania się itd.,

> kooperacja negatywna (inaczej: walka, konflikt, rywalizacja) - jak w przypadku kłótni, negocjacji czy manipulacji.

Poza wyznaczeniem rodzaju kooperacji interlokutorów wyróżnijmy jeszcze za Awdiejewem i Habrajską (2006:43-45) typy kontaktów werbalnych, które dopełniają obraz tego, co się dzieje w spotkaniu między dwiema (lub więcej) osobami: 
1. Kontakty bona-fide, wymagające od uczestników konwersacji szczerości i merytorycznej dyscypliny

a) Kontakty ograniczone tematycznie, np. rozmowy specjalistów lub konwersacje dotyczące wspólnie ustalonego obszaru tematycznego. Dyscyplina merytoryczna zakłada w tym przypadku trzymanie się granic tematycznych (zasada ilościowa).

b) Kontakty ograniczone merytorycznie, w których głównemu celowi rozwiązywaniu postawionych problemów, służą specjalnie wybierane przez mówiących środki argumentacji, definiowania i egzemplifikowania. Stosowanie środków niezwiązanych bezpośrednio z dążeniem do określonego celu jest rozpatrywane jako naruszenie dyscypliny merytorycznej (zasada jakościowa).

2. Kontakty non-bona-fide, niewymagające szczerości i dyscypliny merytorycznej od uczestników interakcji.

a) Gra werbalna - swobodne operowanie środkami językowymi w celach rozrywki i zabawy, dowcipkowanie, opowiadanie kawałów, stylizacja różnych typów kontaktów w celach estetycznych itd.

b) Kontakt konfliktowy - werbalna degradacja partnera.

Warto zaznaczyć również za Awdiejewem, że powyższa typologia kontaktów pod względem tematycznym i merytorycznym nakłada się na typologię kontaktów interakcyjnych opartą na zależności od stopnia wiedzy o partnerze, czyli od stopnia trwałości kontaktu. Z tego punktu widzenia kontakty dzielą się na oficjalne i nieoficjalne:

1. Kontakty nieoficjalne:

a) kontakty rodzinno-domowe (kontakty między osobami bliskimi sobie, zakładające największą wiedzę o interlokutorze),

b) kontakty towarzyskie (nieskrępowane kontakty między przyjaciółmi, zakładające dość obszerną wiedzę o interlokutorze) oraz

c) kontakty profesjonalno-towarzyskie (nieskrępowane kontakty między specjalistami $\mathrm{z}$ danej dziedziny, zakładające obszerną wspólną wiedzę z danej dziedziny).

2. Kontakty oficjalne:

a) oficjalno-towarzyskie (kontrolowane pod względem formy kontakty z ludźmi znajomymi),

b) oficjalno-specjalistyczne (kontrolowane pod względem formy kontakty między specjalistami danej dziedziny),

c) neutralne (kontrolowane pod względem formy i mocno zrytualizowane kontakty z ludźmi nieznajomymi, np. kontakty w miejscach publicznych: w sklepach, w środkach transportu, w biurach itd.). 
Na koniec podkreślmy, że powyższe typy kontaktów i kooperacji przebiegają $\mathrm{w}$ czasie według dających się wyróżnić sekwencji, co modelowane jest przez specjalistów komunikacji (np. modele negocjacji, polemiki, spotkań towarzyskich itd.).7 Powyższe rozważania podsumowuje rys. 2.

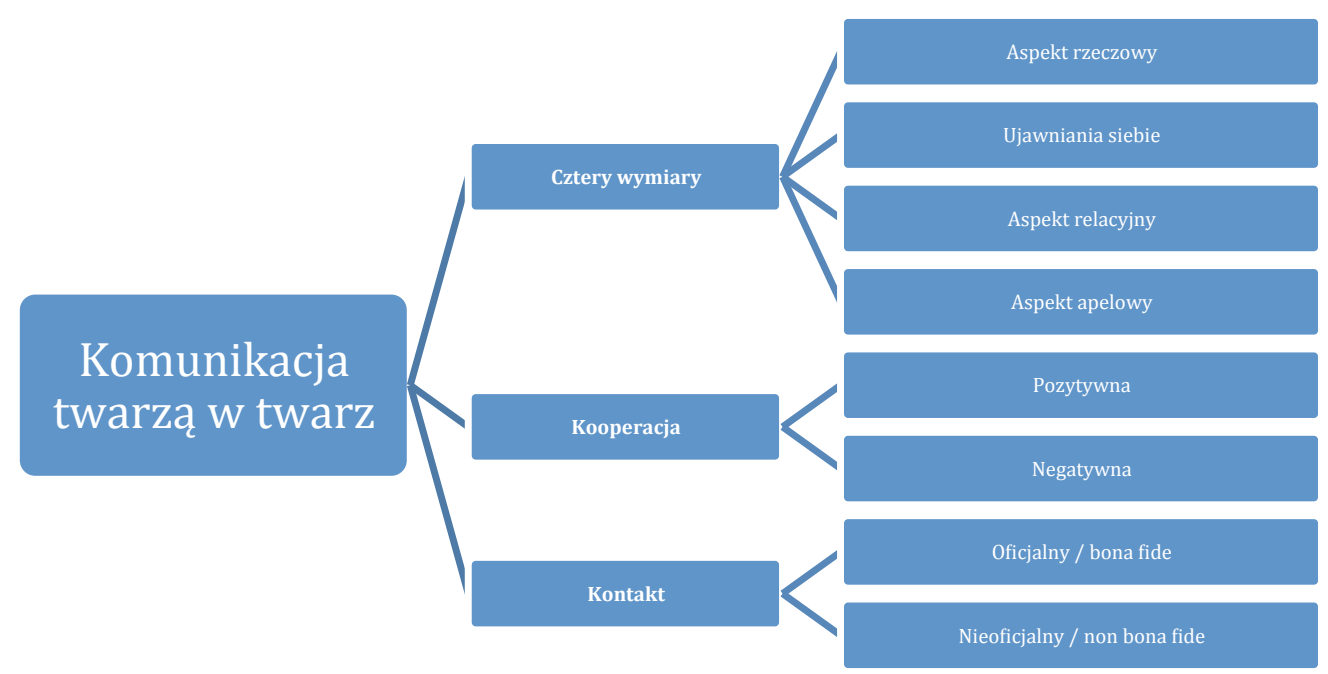

Rys. 2. Trzy główne wymiary opisu komunikacji twarzq w twarz.

\section{0 aksjologicznym na komunikację twarzą w twarz \\ spojrzeniu}

Jak zasygnalizowane zostało $\mathrm{w}$ poprzednich punktach, przestrzeń komunikacyjna wypełniona jest z jednej strony momentami intrygującymi, wyjątkowymi, z drugiej - momentami bez znaczenia czy wręcz nudnymi. Można również wartościować komunikację pod względem tego, czy jest ona konstruktywna, czy też destruktywna, skuteczna czy wadliwa, głęboka czy płytka, refleksyjna czy bezrefleksyjna. A zatem można zaproponować różne formy wartościowania komunikacji międzyludzkiej:

> wartościowanie estetyczne: komunikacja „piękna” i „brzydka”, wzbudzająca zachwyt, wzbudzająca oburzenie, znudzenie, zmęczenie; oryginalna, przeciętna; zabawna, nudna; płynna, niepłynna; zrytualizowana, niekonwencjonalna (oryginalna);

wartościowanie pragmatyczne (utylitarne): komunikacja skuteczna i nieskuteczna; konstruktywna i destruktywna; przynosząca pożytek (korzyść) lub nie (stratę); udana (fortunna), nieudana (niefortunna);

wartościowanie poznawcze: komunikacja głęboka i płytka, autentyczna i sztuczna; rzetelna, nierzetelna; pouczająca, nic nie wnosząca;

7 Por. Nęcki (2000) przedstawia różne modele przebiegu rozmowy; McKay, Davis i Fanning (2001) modelują przebieg tzw. uczciwej kłótni. 
wartościowanie emocjonalne: pozytywna („sympatyczna”) i negatywna (,przykra”); „trudna” i „łatwa” (swobodna);

- wartościowanie etyczne: komunikacja prawdziwa i nieprawdziwa, dobra i zła, skupiona wokół wartości lub nie, społecznie akceptowalna, społecznie nieakceptowalna.

Eric Berne (1999) w swej książce „Dzień dobry i co dalej?” konfrontuje czytelnika z kilkoma pytania: Co mówimy po „dzień dobry”? Jak mówimy „dzień dobry”? Jak odpowiadamy na „dzień dobry”? oraz: Co mówimy, zamiast mówić „dzień dobry”? Zdaniem autora, w istocie pytania te dotyczą fundamentalnych problemów, z jakimi borykamy się na co dzień, kryją się bowiem za nimi takie pytania, jak: Dlaczego ze sobą rozmawiamy?, Dlaczego lubimy być lubiani? Ostatecznie Berne proponuje wyróżnić dwa rodzaje języków, jakimi można się posługiwać w komunikacji. Nazywa je językiem „marsjańskim” i językiem „ziemiańskich” rozmów. Różnica między nimi polega na tym, że ten pierwszy pozbawiony jest tego, co Berne określa metaforycznie „śmietnikiem”, czyli myśli przesłaniających bezpośredni kontakt z rozmówcą i samym sobą. Chodzi o myśli dotyczące przeszłości (np. myśli o przykrościach, których się doświadczyło) lub przyszłości (np. myśli o kłopotach, przez które właśnie będzie trzeba przebrnąć). A zatem Berne skupia się wokół takich wartości w komunikacji, jak autentyczność, prawda, obecność.

Z kolei Schulz von Thun pyta wprost: Czym jest dobra komunikacja? (albo: Jak poprawić komunikację międzyludzką?) (Schulz von Thun 2007a:12, Schulz von Thun 2007b:18). W swej trylogii „Sztuka rozmawiania" autor wyjaśnia, że jakość komunikacji zależy od klarowności. Nic więc dziwnego, że omawia tak podstawowe zagadnienia psychologii komunikacji, jak: autentyczność, otwarte apele, komunikat pełny (tzw. informacja zwrotna), uważne słuchanie, wyczucie sytuacji, samoświadomość.

Dla Stewarta (2007), który wyraźnie odwołuje się do filozofii Bubera i psychoterapii Rogersa, dobra komunikacja to komunikacja międzyosobowa, a nie bezosobowa. Pisze: komunikacja interpersonalna zachodzi między osobami, a nie między rolami, maskami czy stereotypami. Komunikacja interpersonalna między toba a mna może nastapić tylko wtedy, gdy każdy z nas da coś z siebie, a jednocześnie będzie otwarty na taki sam komunikat $z$ drugiej strony (Stewart 2007:26). Stewart skupia się więc na tej jakości w komunikacji, jaką jest kontakt (bliskość, relacja, związek, zjednoczenie).

Perspektywę zorientowaną na badanie skuteczności (czy wręcz doskonałość) w komunikacji przyjęto od początku w programowaniu neurolingwistycznym. O'Connor, Seymour wyjaśniają na wstępie, że NLP dotyczy studiów nad regułami, jakimi kierują się ludzie odnoszący sukcesy w różnych dziedzinach życia (O’Connor, Seymour 1996:21).

Liczne poradniki komunikacji interpersonalnej, które od kilku dekad są publikowane na całym świecie, w pewnym stopniu odzwierciedlają potrzeby istniejące wśród ludzi, by komunikować się w sposób bardziej 
zrozumiały, by uzyskiwać lepszy kontakt $\mathrm{z}$ innymi, by lepiej się prezentować innym i uzyskiwać większy wpływ $\mathrm{w}$ interakcjach społecznych. Badacz komunikacji nie powinien pozostawać ślepym na te potrzeby społeczne, kiedy projektuje swoje badania, jeśli jest zainteresowany dostarczaniem rozwiązań w dziedzinie komunikacji, które są społecznie pożądane. Pojawia się więc kilka pytań:

$>$ Jakie przyjmować założenia teoretyczne w modelowaniu komunikacji twarzą w twarz?

$>$ Jaki przyjąć ogólny model komunikacji?

$>$ Jakie teorie dostarczają siatki pojęciowej, która umożliwi opisywanie, wyjaśnianie i przewidywanie tak złożonej rzeczywistości, jaką jest komunikacja twarzą w twarz?

Odpowiedzi na te pytania pozwolą określić perspektywę teoretyczną, która umożliwia badanie tych aspektów interakcji międzyludzkich, które zostały poddane empirycznej analizie dopiero niedawno (np. empatia badana w paradygmacie neurobiologicznym). W dalszej części niniejszego artykułu podjęta zostanie próba nakreślenia takiej perspektywy oraz rekonstrukcja obrazu komunikacji międzyludzkiej, jaki się wyłania z badań i refleksji współczesnej humanistyki.

\section{O możliwości badania komunikacji twarzą w twarz}

W potocznej, pozaakademickiej refleksji nad porozumiewaniem się ludzi komunikacja może wydawać się niezbadana i niemożliwa do zbadania. Naturalnie w codziennych kontaktach przytrafiają się nam rzeczy zwyczajne, jak wymienianie się faktami niezwiązanymi z interesami interlokutorów, załatwianie bieżących spraw, banalne nieporozumienia i rzeczy niezwyczajne czy wręcz nadzwyczajne. Moga to być momenty oczarowania czyimś uśmiechem lub spojrzeniem, momenty zachwytu czyjąś osobą, chwile rozbawienia zabawną parodią, emocje przeżywane przy opowiadaniu anegdot, stany zahipnotyzowania (wywołanego intencjonalnie lub nieintencjonalnie). Mogą to być również chwile onieśmielenia czyjąś postawą, irytacji czyjąś miną, frustracji czyimś tonem wypowiedzi i ruchami ciała itp. Są to momenty niemal magiczne magiczne, bo wydają się być niemożliwe do zbadania, niemal - bo ich mechanizmy są stale odkrywane przez badaczy komunikacji międzyludzkiej. Komunikacją bowiem zajmują się już od dawna psychologowie, językoznawcy, socjologowie, filozofowie, antropolodzy, a ostatnio również neurobiolodzy i kognitywiści. Nauka dysponuje obecnie odpowiedziami na wiele intrygujących pytań (zob. następny punkt niniejszego artykułu).

Badacz komunikacji staje więc oto przed następującą sytuacją: przedstawiciele różnych nauk dostarczają wielu wniosków w wycinkach badanej przez siebie rzeczywistości. Pojawia się więc przed nim wyzwanie zsyntezowania dostępnej wiedzy na temat badanej przez niego przestrzeni komunikacyjnej. Podobnie jak kognitywista, który stara się odtworzyć 
całościowy obraz umysłu, korzystając z różnych dyscyplin naukowych, również komunikolog zmuszony jest posiłkować się ustaleniami z różnych dziedzin wiedzy. W związku z tym, że ustalenia te mogą pochodzić zarówno z koncepcji o charakterze filozoficzno-spekulacyjnym, jak i z badań empirycznych, wymagana jest tutaj ciągła konfrontacja tych perspektyw, swoisty metadyskurs (Craig 1999). Taki negocjacyjny charakter konstruowania teorii może mieć właśnie współczesna komunikologia.

Można tu wymienić kilka obszarów, z których czerpie (lub może czerpać) komunikolog:

> dyscypliny szczegółowe: filozofia (filozofia dialogu, filozofia języka, filozofia komunikacji; prakseologia), antropologia, socjologia, językoznawstwo (lingwistyka kognitywna, gramatyka komunikacyjna), pragmalingwistyka, psychologia komunikacji (np. według Schulza von Thuna), semiotyka, retoryka i erystyka, psychologia społeczna, psychologia poznawcza, psychologia emocji i motywacji, psychologia osobowości i różnic indywidualnych, psychologia humanistyczna;

> nauki interdyscyplinarne: kognitywistyka, psycholingwistyka, analiza dyskursu, affective science, social neuroscience, humorologia (humour research);

modele praktyczne: programowanie neurolingwistyczne, Porozumienie Bez Przemocy, trening asertywności, Analiza Transakcyjna Berne'a, coaching;

psychoterapia8: psychoterapia zorientowana na klienta, psychoterapie somatyczne, psychoterapie kognitywnobehawioralne;

inne: teoria aktorstwa, teatrologia, biomechanika.

\section{Jaką przyjąć perspektywę w studiach nad komunikacją bezpośrednią?}

Proces poznania naukowego wiąże się $\mathrm{z}$ przyjęciem pewnych założeń wstępnych dotyczących samego badanego wycinka rzeczywistości, jak i sposobu jego badania. Założenia te istotnie rzutują na kierunek i przebieg tego procesu, a więc badacz musi szczególnie starannie uświadomić sobie przyjmowaną perspektywę i poddać ją refleksji i ocenie.

Przyjmując, jak już to zostało na wstępie podkreślone, że komunikacja bezpośrednia jest podstawową formą komunikacji, należy uznać, że zakres przedmiotu badawczego, tj. dziedzinę badawczą, stanowią ludzie (aktorzy społeczni) i interakcje (aktywności), w których uczestniczą. Założenia powinny zatem dotyczyć zarówno charakterystyki istot komunikujących się (założenia psychologiczne), jak i samej komunikacji (założenia stricte komunikologiczne).

\footnotetext{
${ }^{8}$ Warto podkreślić, że praktyka psychoterapeutyczna przez wiele dekad stanowiła pole doświadczalne i źródło wielu inspirujących myśli dla badaczy komunikacji międzyludzkiej.
} 
Szczególnie ważna jest refleksja nad założeniami dotyczącymi ludzi, gdyż to właśnie natura ludzka kształtuje komunikację między nimi. Poniżej więc przedstawione zostaną te założenia psychologiczne, które szczególnie często wykorzystywane są przy modelowaniu komunikacji międzyludzkiej w ramach różnych koncepcji i modeli komunikacji.

\subsection{Człowiek jest istotą relacyjną i społeczną (Dwyer 2005; Argyle 1972; Stewart 2007).}

Kozłowski (2007:20) stwierdza, że istotą społeczną człowiek się staje. Wtapiamy się w kontekst kulturowy. Uczymy się norm i przyjmowania ról. Warto jednak pamiętać, że choć przeznaczone jest nam stać się istotą społeczną, to rodzimy się już z silnym instynktem do tworzenia więzi. Dlatego możemy mówić, że z urodzenia jesteśmy istotami relacyjnymi. Marcher9, która prowadzila wieloletnie badania nad rozwojem psychomotorycznym dzieci, doszła do wniosku, że główną siłą napędową ludzkich działań jest pragnienie pozostawania $\mathrm{w}$ lączności $\mathrm{z}$ innymi i otoczeniem. Nazywa to popędem (dążeniem) ku wzajemnej łączności (drive toward mutual connection) (zob. Bernhardt 2004). Innymi słowy, człowiek dąży do tworzenia relacji z innymi, a nie do izolacji czy wycofania (co można $\mathrm{w}$ świetle tej tezy uznać za patologiczne). Tak o tym pisze Stewart:

(...) $\mathrm{w}$ świecie ludzkim istnieje podstawowy ruch skierowany na związek, a nie na oddzielenie. (...) Ludzie są istotami relacyjnymi, a nie odizolowanymi. Nasza natura i egzystencja domaga się kontaktu $\mathrm{z}$ innymi osobami (Stewart 2007:31).

Współczesna neurobiologia (a konkretniej - neurobiologia społeczna) potwierdza tę starą prawdę. Referując wyniki badań tej dopiero rodzącej się dziedziny nauki, Goleman pisze:

Najbardziej fundamentalnym objawieniem owej dyscypliny jest to, iż nasze obwody nerwowe są tak skonstruowane, byśmy się ze sobą łączyli. Neurobiologia odkryła, że sam układ naszego mózgu sprawia, iż jest on towarzyski i nieuchronnie daje się wciagnaç $\mathrm{w}$ intymny związek z drugim mózgiem za każdym razem, gdy kontaktujemy się z inną osobą. To połączenie nerwowe pozwala nam wpływać na mózg - a zatem również na ciało

9 Lisbeth Marcher jest twórczynią szkoły psychoterapii somatycznej, nazwanej przez nią analizą bodynamiczną, a także założycielką Instytutu Bodynamiki w Kopenhadze. Istotnym dokonaniem Marcher jest przeprowadzenie projektu badawczego, w ramach którego przez wiele lat jej zespół analizował powiązania między stanami napięć i wiotkości mięśni a treściami psychicznymi, czego efektem było wypracowanie unikalnego modelu rozwoju psychomotorycznego (zob. Macnaughton 2004). 
- każdego, z kim nawiązujemy kontakt, a jemu wpływać na nasz mózg i ciało (Goleman 2007:11).

Widocznym przejawem omawianej tutaj tendencji człowieka jest jego dopasowywanie się do innych ludzi. Nietrudno zauważyć, że ludzie dostrajają się do siebie nawzajem. Codzienne obserwacje dostarczają wielu przykładów tego zjawiska: ludzie na ulicy chodzą w podobnym tempie, w autobusach i tramwajach tak samo unikają kontaktu wzrokowego, ludzie ubierają się podobnie $\mathrm{w}$ danym miejscu pracy, dopasowujemy używany język, głośność mówienia, gesty, miny itd. Dużo mniej oczywiste jest to, jak subtelny jest ten proces w kontakcie twarzą w twarz. Chartrand, Maddux i Lakin (2005) referują badania świadczące o tym, że ludzie automatycznie naśladują się nawzajem w wymiarze zarówno werbalnym (naśladowanie konkretnych słów, zdań, gramatyki całych zdań, akcentu, tempa mówienia, tonu głosu, rytmu mowy, długości trwania pauz, ilości wypowiedzień, prawdopodobieństwa przerwania ciszy, śmiechu partnerów interakcyjnych), jak i niewerbalnym (naśladowanie ekspresji mimicznych, postaw, gestów, konkretnych ruchów interlokutora). Co więcej, odkryto również, że interlokutorzy mogą wykonywać nieznaczne ruchy mięśni twarzowych w trakcie przejmowania wyrazu twarzy drugiego człowieka (można to określić mikromimikrą). Badacze stwierdzają, że zebrane wyniki badań sugerują, iż mimikra jest powszechnym zachowaniem, które ma wiele form $i$ jest wykonywana automatycznie $w$ najróżniejszych okolicznościach (w kontakcie z bliskimi, członkami rodziny, przyjaciółmi, nauczycielami, ale także z obcymi). Wyjaśniają również, że automatyczna mimikra jest funkcjonalna i spełnia rolę adaptacyjną, gdyż kreuje więź między ludzmi, stymuluje empatię, sympatię i płynne interakcje.

Pomimo tego, że jesteśmy istotami nastawionymi na kontakt i tworzenie związków z innymi, nie wyklucza to konfliktów między nami. Ciekawym zjawiskiem w tym kontekście jest opisane przez Schulza von Thuna tzw. „diabelskie koło relacji”. Z „diabelskim kołem” mamy zawsze do czynienia, gdy pojawia się zaburzenie w systemie (diadzie, rodzinie, grupie pracowniczej, instytucji itd.). Istotne jest tutaj to, że nie szuka się zaburzonych jednostek $\mathrm{w}$ systemie (innymi słowy nie ma jednego winnego), ale zakłada się, że cały system jest zaburzony. Zgodnie z takim systemowym podejściem do komunikacji międzyludzkiej ludzie mają tendencję do wikłania się w relacje współuzależnienia, w których powtarzane są te same schematy akcji i reakcji, np. oskarżanie wycofywanie się - oskarżanie - wycofywanie się - oskarżanie... itd. Takie zaburzone relacje (i wzorce komunikacji) mogą przyjmować różne formyio, jednak, co jest w nich interesujące, to właśnie fakt podtrzymywania tych relacji. Zjawisko to pokazuje, jak silna jest potrzeba do podtrzymywania

${ }^{10} \mathrm{~Np}$. cykl wzajemnych oskarżeń, cykl: zachowanie świadczące o bezradności zachowanie wspierające. 
więzi $\mathrm{z}$ drugim człowiekiem, pomimo że może ona być już niekonstruktywna (Schulz von Thun 2007b) ${ }^{11}$.

Współczesna literatura poświęcona komunikacji twarzą w twarz zdaje się koncentrować na relacji, jaka tworzy się w toku komunikacji (Stewart 2007; Schulz von Thun 2007; Fogel 1993; Goleman 2007; Nęcki 2000). Perspektywa ta zaczyna być również dostrzegana na gruncie językoznawstwa. Małgorzata Kita pisze:

Pomijana często przez lingwistów, zajętych badaniem aspektu semantycznego wypowiedzi, relacja zajmuje $\mathrm{w}$ komunikacji ludzkiej miejsce bardzo istotne (Kita 2001:171).

Również Awdiejew, który zainicjował i od lat współtworzy polską gramatykę komunikacyjną, utożsamia analizę interakcji z badaniem zmian zachodzących w relacji między interlokutorami (Awdiejew, Habrajska 2006:22).

Teza o relacyjnej naturze człowieka na gruncie refleksji nad komunikacją znalazła wyraz w postaci wyeksponowania dwóch poziomów (wymiarów) komunikacji: treściowego i relacyjnego. W przeglądzie teorii komunikacji dokonanym przez Nęckiego (2000) można znaleźć porównywalne podziały:

content level i relationship level w koncepcji szkoły Palo Alto,

funkcja „reprezentacji” i funkcja „prezentacji stosunku” (Danziger),

report i command w koncepcji Batesona.

Na gruncie językoznawstwa podobny podział można znaleźć w refleksji nad funkcjami języka. Kurcz (2000) wskazuje na dwie podstawowe funkcje: reprezentatywną i komunikacyjną; również Evans i Green (2006) wyróżniają funkcje: symboliczną i interakcyjną ${ }^{12}$.

Warto na koniec podkreślić, że proponenci relacyjnego spojrzenia na komunikację akcentują przewagę procesów zachodzących na poziomie relacyjnym nad samym przepływem informacji. Prawdopodobnie pierwszym teoretykiem komunikacji, który przyjął takie stanowisko, był Watzlawick. Swoją intuicję sformułował on w następujący sposób: Jakaś piąta część całej komunikacji ludzkiej służy dla wymiany informacji, podczas gdy reszta dotyczy niekończącego się procesu definiowania, potwierdzania, negowania i redefinicji istoty naszych relacji $\mathrm{z}$ innymi (Watzlawick, za: Nęcki 2000).

11 Por. Goleman (1997:207-234) opisuje tzw. pat małżeński, w którym stosunki zaczynają się układać według wzoru: zaangażowanie - wycofanie się.

12 Por. gramatyka komunikacyjna Awdiejewa oparta jest na podobnym, przyjętym za Halliday'em, wyróżnieniu funkcji komunikacyjnych języka: ideacyjna, interakcyjna i tekstowa (za: Awdiejew i Habrajska 2004). 
Innymi słowy, zgodnie $\mathrm{z}$ tym poglądem ludzie są prawie zawsze bardziej zainteresowani tym, jak są traktowani (i odbierani) przez rozmówców oraz jaka wyłania się między nimi definicja relacji niż tym, czego dotyczy w danej chwili rozmowa. Jeszcze inaczej to ujmując, przekazywane przez rozmówcę informacje o wzajemnej relacji zawsze dotykają odbiorcę bardziej niż informacje dotyczące omawianych spraw (zob. Stewart 2007, Pentland 2008).

\subsection{Człowieka charakteryzuje wewnętrzna mnogość i dialogowość}

Idea, jakoby psychika człowieka składała się z kilku względnie odrębnych stanów ego (stanów „ja”, jaźni), jest bardzo stara. Rogoll (1989) przywołuje starożytną koncepcję wewnętrznego podziału człowieka na trzy jednostki funkcjonalne: „Niewolnika” odpowiedzialnego za popędy i uczucia jednostki, „Mistrza” rozważającego problemy życiowe i decydującego o tym, co należy przyjąć, a co odrzucić i „Strażnika” kontrolującego zachowanie całej jednostki ${ }^{13}$. Podział ten, łudząco podobny, odnaleźć można w koncepcji Freuda, który wyróżnił id, ego i superego. Również w ramach analizy strukturalnej Erica Berne’a wyróżnione zostały stany Dziecka, Dorosłego i Rodzica (Berne 2001:16). Taka multifreniczna koncepcja człowieka u swej podstawy zakłada jego wewnętrzną różnorodność (mnogość, niejednorodność) i wynikającą z niej wewnętrzną dynamikę (dialog, spór). Zauważmy, że ta rzeczywistość psychiczna ujmowana była $\mathrm{w}$ różny sposób, np. jako walka emocji i rozumu, id i superego, dysonans między elementami poznawczymi ${ }^{14}$ itd. Chociaż sformułowano wiele różnych koncepcji starających się ująć tę psychodynamikę, a także wyodrębniono różne kategorie bytów psychicznych, pomiędzy którymi dochodzi do „dialogu” (stany ego, postawy, procesy emocjonalne i poznawcze, popędy, wartości, pragnienia, impulsy, moduły, style poznawcze itd.), to można przyjąć, że idea wewnętrznej mnogości i dynamiki utrzymuje się $\mathrm{w}$ naukach humanistycznych i wciąż stanowi elegancki i wpływowy sposób opisu złożonej rzeczywistości psychicznej człowieka15.

Ideę wewnętrznej różnorodności dopełnia zawsze idea wewnętrznych konfliktów ${ }^{16}$. W związku ze złożonością jego struktury psychicznej,

\footnotetext{
13 Można doszukiwać się podobieństwa tej triady do podziału na logos, pathos i ethos.

14 Por. „Jesteśmy organizmami złożonymi; w każdej chwili niezliczone liczby krzyżujących się motywów wpływają na nasze myślenie i zachowanie“ (Aronson i inni 1997:19).

${ }_{15}$ Schulz von Thun zwraca również uwagę na popularność tej idei w literaturze i poezji i przytacza następujące przykłady: „Wilk Stepowy“ Hessa, „Doktor Jekyll i Pan Hyde“ Stevensona, „Wojna i pokój“ Tołstoja, „Faust“ Goethego (Schulz von Thun 2007(c):71).

16 Por. koncepcja konfliktów wewnętrznych w psychoanalizie, teoria dysonansu poznawczego Festingera.
} 
człowiekiem targają sprzeczności. W badaniach nad komunikacją istotne jest to, że ta wewnętrzna dynamika znajduje odzwierciedlenie na kilku poziomach komunikacji. Można przyjąć, że takie wewnętrzne niespójności mogą znaleźć wyraz na trzech poziomach:

$>$ wewnątrz tego, co mówimy (tj. wypowiedź wewnętrznie niespójna),

$>$ między tym, co mówimy, a tym, jak mówimy (tj. treść wypowiedzi jest niezgodna z przekazem wyrażonym w głosie lub ciałem) oraz

> wewnątrz tego, jak mówimy (tj. wewnątrz samego komunikatu niewerbalnego).

Koncepcja o wewnętrznej mnogości i wewnętrznych konfliktach okazała się bardzo użyteczna w tworzeniu modeli komunikacji oraz $\mathrm{w}$ opisywaniu i wyjaśnianiu zachowań interpersonalnych. Oparta na niej jest Analiza Transakcyjna Erica Berne'a (1999), koncepcja metaprogramów w programowaniu neurolingwistycznym (O'Connor, Seymour 1996), a także psychologia komunikacji Schulza von Thuny (2007c). Ten ostatni, korzystając $\mathrm{z}$ metafory dynamiki grupowej, opracował koncepcję wewnętrznego zespołu. Można ją uznać za swoistą komunikacyjną koncepcję umysłu, tj. za efekt twórczego przeniesienia wiedzy na temat komunikacji międzyludzkiej na pole refleksji nad psychiką człowieka.

Takie zjawiska komunikacyjne, jak autentyczność (spójność, zgodność), kłamstwo, nieporozumienia, manewrowanie relacjami, komunikaty sprzeczne (tzw. podwójne wiązanie) dają się opisać i wyjaśnić dzięki wyżej wymienionym modelom psycho-komunikacyjnym.

W literaturze poświęconej komunikacji interpersonalnej jednym z kluczowych zagadnień jest problem kłamstwa w komunikacji. Sarnowska i inni (2006) stwierdzają:

Kłamiemy i jesteśmy okłamywani na co dzień. Być może dlatego mamy do kłamstwa stosunek dwuznaczny: potępiamy je, ale równocześnie chętnie je stosujemy.

Co ciekawe, ludzie wydają się być bardzo wprawni w kłamaniu. Co więcej, samo kłamstwo można uznać za nie tylko popularne, ale również bardzo skuteczne, może nawet podstawowe narzędzie realizowania różnych celów interpersonalnych. Pomimo wprawy w kłamaniu badania wskazują, że wprawa ta nie obejmuje rozpoznawania kłamstw u innych. Aronson, Wilson i Akert wyjaśniają: ogólnie jednak zdolność ludzi do odkrywania oszustwa nie jest szczególnie wysoka. Mamy tendencję do wyjaśniania wątpliwości na korzyść innych, do zakładania, że mówia prawdę ${ }^{17}$. Co więcej, nawet gdy badani wiedza, kto kłamie, to zwykle nie potrafia określić, co dana osoba naprawdę odczuwa - innymi słowy, jaka prawde przykrywa kłamstwo (1997:180). Paul Ekman, który przeprowadził szczegółowe badania w tym zakresie, wnioskuje, że tylko 1\% ogólnej populacji potrafi wychwycić kłamców na podstawie ich zachowania (zob. efekt Diogenesa - Ekman 2007). Tymczasem nasze ciała są

${ }_{17}$ Por. zasada życzliwości w pragmatyce językowej. 
niezdyscyplinowane i nie poddają się takiej łatwej manipulacji jak słowa, którymi o wiele wprawniej kłamiemy. Między innymi dlatego właśnie język ciała jest uznawany za szczególnie ważny kod komunikacyjny. Zadziwiająca jest tutaj siła mechanizmów zmierzających do ujawnienia prawdziwych stanów przez ciało. Ekman opisał tutaj tzw. „wycieki” - czyli niepoddające się kontroli spontaniczne mikro-ekspresje zdradzające to, co ktoś naprawdę czuje.

Pomijając ocenę natury etycznej zjawiska kłamstwa, należy uznać, że badania nad komunikacją muszą uwzględniać ten aspekt porozumiewania się. W jego opisie użyteczne okazują się modele ujmujące psychikę człowieka jako wewnętrznie złożoną i dynamiczną. Istotne jest również to, by w tym opisie uwzględnić język ciała jako szczególnie ważny w kontekście badania kłamstwa interpersonalnego.

\subsection{Człowiek jest istotą przede wszystkim emocjonalną, a dopiero $w$ drugim rzędzie racjonalną}

Rozróżnienie na rozum i serce sięga starożytności. Jak pisze LeDoux:

Od czasów starożytnych Greków ludzie uważają za konieczne oddzielanie rozsądku od namiętności, myślenia od uczucia, poznania od emocji. (LeDoux 2000:27)

Zajenkowski (2004), poddając analizie definicje różnych pojęć psychologicznych (,inteligencja”, „osobowość”, „motywacja”, „styl poznawczy" itd.), a także ustalając kryteria elementarności przedmiotów mentalnych, wykazuje, że takimi właśnie najprostszymi, podstawowymi, pierwotnymi procesami ${ }^{18}$ psychicznymi (umysłowymi) są: poznanie i emocje. Podział ten zdaje się być dobrze ugruntowany w naukach humanistycznych (Zajenkowski 2004; Goleman 1997; Parkinson i Colman 1999). We współczesnej psychologii dyskurs na temat wzajemnego stosunku poznania i emocji został zainicjowany słynnym referatem Zajonca z 1979 roku, zatytułowanym „Czucie i myślenie. Preferencjom niepotrzebne są inferencje" (Feeling and Thinking: Preferences Need no Inferences) (zob. LeDoux 2000:61; De Houwer i Hermans 2010:38). Ewolucję podejścia do tego zagadnienia doskonale podsumowuje opinia Tomalskiego:

(...) afekty, emocje i uczucia mogą być podstawowymi elementami, które inicjują i koordynują zachowania oraz aktywność mentalną. Czy w takim przypadku badanie wysublimowanych procesow poznawczych i ich korelatow mózgowych nie traci sensu, czy zamiast o cognitive neuroscience nie powinniśmy mówić o affective neuroscience? Niestety, w Obliczeniowej Teorii Umysłu

18 Autor używa również terminów „czynniki”, składniki”, „przedmioty”, „podstawy”, a także „elementarne jednostki”. 
nie znalazło się wiele miejsca dla procesów emocjonalnych. (Tomalski 2004:169)

Szczególnie ważne w tej długiej dyskusji na temat wzajemnych związków emocji i poznania są badania LeDoux. Dostarczają one bowiem wsparcia empirycznego dla stanowiska, które głosi względną niezależność systemów emocjonalnego i poznawczego (czy jak pisze Goleman (1997) niezależność umysłu emocjonalnego i racjonalnego, serca i rozumu).

Szczegółowy opis teoretyczny takiego ujęcia emocji przedstawił Wiener (2006), który zaproponował, by emocje traktować jako antycypacje, a nie percepcje. Korzystając z rozróżnienia Gärdenforsa (2010) na trzy główne reprezentacje mentalne organizmów żywych wrażenia, percepcje i wyobrażenia - emocje należałoby wiązać przede wszystkim z tymi pierwszymi (które, dodajmy, są również ewolucyjnie wcześniejsze od dwóch ostatnich) ${ }^{19}$.

A zatem nie dość, że wykazuje się względną niezależność procesów emocjonalnych od poznawczych (przy najmniej w tym sensie, że te pierwsze nie wymagają percepcji, czy kognitywnej oceny rozpoznanego bodźca afektywnego), to wielu badaczy i teoretyków uznaje emocje za centralne dla życia psychicznego (zob. Damasio, LeDoux, Oatley i Jenkins, Goleman). Jak to ujmuje Casacuberta:

Nasze emocje znajdują się w samym jądrze racjonalności. Bez nich nie bylibyśmy umotywowani, a bez motywacji nie moglibyśmy podejmować decyzji, rozwiązywać problemów, a nawet racjonalnie myśleć (Casacuberta 2007:182).

To od emocji zależy nasza świadomość, inteligencja, motywacja i podejmowanie decyzji. Naturalnie systemy emocjonalny i racjonalny często współpracują ze sobą, jednak sam układ racjonalny bez pomocy emocji nie byłby w stanie podjacć praktycznie żadnej decyzji, bo po prostu nie wiedziałby, co jest dla organizmu istotne (ważne). A zatem wszystkie nasze decyzje są przesiąknięte emocjami (Casacuberta 2007:172; Kalat 2011:356; Johnston 1999:179).

Dodatkowo psycholodzy skłonni są obecnie twierdzić, że nie tyle jesteśmy racjonalni, co skłonni do racjonalizacji. Przykładowo Aronson i Pratkanis piszą: My ludzie lubimy myśleć o sobie jako o zwierzętach racjonalnych. Jednak bliższe prawdy byłoby stwierdzenie, że jesteśmy skłonni do racjonalizacji, że bez względu na to, jak irracjonalnie zachowujemy się $w$ rzeczywistości, chcemy wydawać się rozsądni

19 Wiener określa bodźce aktywujące system emocjonalny (przede wszystkim ciało migdałowate) „zwiastunem“, Goleman „niedokładnym sygnałym“ albo „ostrzeżeniem“, „oznaką“ (Goleman 1997:52-53). Uwagi te uzasadniają postulowane $\mathrm{w}$ dalszej części artykułu rozdzielenie w komunikacji symptomów (oznak) od sygnałów i symboli. 
zarówno sobie, jak i innym (Aronson i Pratkanis 2004:39). Badania przeprowadzone przez psychologów społecznych wykazują, że gdy przekonania racjonalne wchodzą $\mathrm{w}$ konflikt z tymi bardziej osobistymi, ważnymi przekonaniami, zwłaszcza dotyczącymi autoobrazu danej osoby, to rozum przegrywa $\mathrm{z}$ emocjami. Radzenie sobie $\mathrm{z}$ napięciem spowodowanym sprzecznością dwóch elementów poznawczych sprowadza się zwykle do korzystania z różnego rodzaju mechanizmów irracjonalnych: tłumienie, racjonalizacja, reinterpretacja itd. (zob. Aronson, Wilson, Akert 1997:83; Szymanek 2001:121-123).

W tym kontekście warto również wspomnieć o badaniach Tversky'ego i Kahnemana, które wykazały, iż ludzie nie są racjonalni, częściej bowiem korzystają z różnego rodzaju „skrótów myślenia”, zwanych heurystykami poznawczymi (zob. Nęcka i inni 2006).

W zgodzie z powyższymi ustaleniami pozostaje preskryptywny model komunikacji zaproponowany przez Rosenberga, zwany Porozumieniem Bez Przemocy (PBP) ${ }^{20}$. Wychodząc z założenia, że komunikacja służy zaspokajaniu potrzeb, Rosenberg postuluje, by koncentrować się na ich identyfikowaniu i wyrażaniu $\mathrm{w}$ trakcie porozumiewania się $\mathrm{z}$ innymi. Emocje i uczucia są tutaj traktowane jako sygnały niezaspokojenia lub zaspokojenia potrzeb. A zatem postulowana w ramach PBP dobra komunikacja ma zasadzać się na otwartym wyrażaniu emocji i stojących za nimi potrzeb oraz na wsłuchiwaniu się $\mathrm{w}$ nie $\mathrm{w}$ wypowiedziach rozmówców. Podejście to jest przeciwstawiane różnym formom nacisku, perswazji, manipulacji, motywowania, które w PBP określane są jako szeroko rozumiana przemoc. Uznaje się, że naturalnym mechanizmem regulującym kooperację i wzajemną pomoc między ludźmi jest empatia (i współczucie), a komunikacja powinna na niej bazować (Rosenberg 2003; Rust 2010).

W ostatnich latach napisano wiele artykułów i opracowań poświęconych zjawisku „zarażania emocjonalnego”. Daniel Goleman (2007) stwierdza:

(...) emocje są zaraźliwe. (...) Każdy kontakt z drugą osobą ma emocjonalny podtekst. Wraz ztym, co robimy, możemy sobie nawzajem nieco, a nawet bardzo poprawić samopoczucie albo nieco czy (...) bardzo je pogorszyć. (...) Tego rodzaju zarażenie jest $\mathrm{w}$ emocjonalnej gospodarce główną transakcją, wzajemną wymianą uczuć, która towarzyszy każdemu kontaktowi, jaki nawiązujemy $\mathrm{z}$ innym człowiekiem, bez względu na to, w jakiej pozornie sprawie się z nim kontaktujemy (Goleman 2007:24 i 26).

Istotne jest również to, że zarażenie emocjonalne jest przykładem tego, co można nazwać działaniem „niskiej drogi“ w mózgu. Oznacza to, że tworzą ją połączenia nerwowe, które działają pod progiem świadomości (Goleman 2007). Poza tym istotne dla przedstawianych w niniejszym

${ }^{20}$ Ang.: Nonviolent Communication (NVC). 
artykule rozważań jest wyjaśnienie, iż ta przemożna emocjonalna wymiana realizowana jest niewerbalnie $\mathrm{w}$ wyniku nieświadomego naśladowania mimiki, postaw i ruchów ciała innych osób (Wróbel 2005).

\subsection{Zachowanie człowieka jest regulowane bardziej przez procesy nieświadome niż świadome}

Pierwszym, który sformułował taką tezę, był Freud21. Opisując psychikę ludzką, zaproponował on metaforę góry lodowej, której widoczny szczyt jest zdecydowanie najmniejszą częścią całego obiektu. Innymi słowy, stosunek świadomych treści wobec nieświadomych odpowiada stosunkowi tego, co widoczne i przykryte pod powierzchnią wody w przypadku góry lodowej. Współczesne badania psychologiczne i kognitywistyczne potwierdzają tę tezę (zob. Ohme 2002). Szczególnie wymowne są wyniki badań nad przetwarzaniem informacji sensorycznych. Dijksterhuis, Aarts i Smith (2005) przywołują wyniki badań, zgodnie z którymi nasze zmysły zbierają ponad 11 milionów bitów informacji w każdej sekundzie, podczas gdy $\mathrm{w}$ tej samej sekundzie jesteśmy $\mathrm{w}$ stanie uświadomić sobie maksymalnie 50 bitów. Innymi słowy, świadomość może poradzić sobie z niewielkim procentem wszystkich dopływających informacji. Cała reszta jest przetwarzana bez udziału świadomości w procesach automatycznych lub całkowicie ignorowana dzięki wewnętrznym mechanizmom hamowania (Wróbel 2001:24). Wnioski te wspierają tezę konstruktywistów (zob. kolejny punkt: 5.5). Wróbel zauważa, że powyższe ustalenia implikują to, że nigdy nie zobaczymy świata nieprzefiltrowanego przez własny mózg i jesteśmy na zawsze skazani na subiektywizm ograniczonej percepcji (Wróbel 2001:24). Co istotne, również tzw. wyższe procesy poznawcze podlegają procesom nieświadomym, o czym pisze Herzyk: Zdecydowana większość procesów regulacji mózgowej przebiega $w$ sposób nieuświadamiany $i$ obejmuje procesy emocjonalne, pamięć, percepcję, uczenie się - $w$ ten sposób tworzy się system wiedzy nieświadomej. Świadoma dowolna kontrola obejmuje końcowe, finalne etapy przetwarzania informacji (podkreślenie - WL) i zapewnia możliwość dowolnych, racjonalnych, planowanych, zmiennych $i$ kreatywnych dziatań oraz wglad i autorefleksję (Herzyk 2001:54). Stąd w psychologii poznawczej człowieka określa się skąpcem poznawczym, a założenie o ekonomii przebiegu procesów przetwarzania informacji uznaje się za podstawowe (Nęcka i inni 2006:25; Aronson i inni 1997:128). Umysł człowieka cechuje ograniczona pojemność. Aby ochronić się przed niebezpieczeństwem przeciążenia informacyjnego, selekcjonujemy dane na różnych etapach przetwarzania. Selekcję tę umożliwia mechanizm uwagi, a także zdolność do hamowania

21 „Procesy duchowe są w swej istocie nieświadome, procesy zaś świadome stanowią jedynie (...) części całego życia psychicznego" (Freud 2010). 
zbędnych reakcji i procesów mentalnych. Skąpstwo poznawcze ujawnia się również - jak pisze Nęcka i współpracownicy - we wszechobecnej w ludzkim poznaniu skłonności do stosowania uproszczonych heurystyk, schematów, stereotypów i innych narzędzi poznawczego upraszczania rzeczywistości. Dodajmy również za Fogelem (2009), że efektywnym mechanizmem selekcji wrażeń ze względu na ich ważność, decydującym o tym, gdzie lokować świadomość, jest emocja - nasz „zmysł”, poczucie, czy coś jest dobre czy złe dla nas (szkodliwe czy korzystne) oraz towarzysząca temu motywacja (chęć, popęd, impuls, intencja), by podejść albo wycofać się (Fogel 2009:55-56).

Z powyższych ustaleń wyłania się wizja człowieka, który przez większość życia polega na swoich mechanizmach automatycznych i nieświadomych. Koncepcja taka przeniknęla już dawno do literatury poradnikowej. Przykładowo Hogan pisze: Większość ludzi działa na zasadzie bodziec-reakcja. Coś się dzieje; oni reaguja. Dzieje się coś innego; oni reagujq (Hogan 2001:28), a Ury stwierdza - Ludzie sq „reagującymi maszynami” (Ury 2004:26).

$\mathrm{Na}$ polu badań nad komunikacją interpersonalną powyższa teza znalazła wyraz w modelu Penmana, który uwzględnia dwa poziomy komunikacji: obserwowalny (powierzchniowy) - bardziej związany z kodem słownym i ukryty (głęboki) - bardziej związany z przekazem niewerbalnym (za: Nęcki 2000:82-83). Również w Analizie Transakcyjnej mowa jest o dwóch rodzajach transakcji: jawnych i ukrytych. Zasadność wyodrębnienia dwóch poziomów komunikacji (świadomego-werbalnego i nieświadomego-niewerbalnego) została niedawno udowodniona $\mathrm{w}$ serii eksperymentów przeprowadzonych przez Pentlanda. Co więcej, badania Pentlanda potwierdzily w sposób ilościowy potoczną wiedzę o dominacji nieświadomej komunikacji nad świadomą. W ostatnich latach zespół Pentlanda przeprowadzil szereg eksperymentów przy wykorzystaniu specjalnie zaprojektowanej aparatury (zwanej socjometrem) do mierzenia interakcji twarzą w twarz. Wyniki badań Pentland (2008) opisał w książce „Honest Signals”. Jego ustalenia można podsumować w następujących punktach:

1. Istnieją dwa kanały komunikacji: społeczny, nieświadomy, który działa bez użycia słów i językowy, świadomy. Sygnały społeczne nie tworzą jedynie kanału zwrotnego lub uzupełniającego w stosunku do przekazu wysyłanego świadomie drogą językową; współtworzą oddzielny kanał komunikacji, który istotnie wpływa na zachowania interlokutorów.

2. Treść relacyjna (społeczna) okazuje się mieć większy wpływ na decyzje słuchaczy niż zawartość merytoryczna przekazywana za pośrednictwem słów. Wpływ ten jest w dużej mierze poza naszą świadomością.

3. Treść relacyjna (społeczna) dotyczy takich aspektów, jak: pewność siebie mówiącego, jego determinacja, wiara $\mathrm{w}$ prezentowane idee itp. Wiąże się z postawą mówiącego, jego intencjami, celami i wartościami.

4. Przekazywanie tej treści odbywa się za pośrednictwem tzw. wiarygodnych sygnałów (honest signals), które Pentland definiuje jako sygnały będące tak kosztowne $\mathrm{w}$ wykonaniu lub tak trudne do 
stłumienia, że stają się wiarygodnymi wskaźnikami intencji i użytecznymi modulantami zachowań obserwatorów. Innymi słowy, są to sygnały nieświadome i niekontrolowalne. Pentland przyjmuje, że badany przez niego kanał komunikacji jest ewolucyjnie starszy od komunikacji językowej i że związany jest $\mathrm{z}$ aktywnością określonych struktur w mózgu (w przeważającej mierze tych ewolucyjnie starszych). Ustalenia te streszczone zostały w Tabeli 2.

5. Mierzenie sygnałów przekazywanych na poziomie relacyjnym ma moc predykcyjną - pozwala przewidywać rezultaty różnych spotkań: rozmów kwalifikacyjnych, negocjacji płacowych, prac zespołów zadaniowych, spotkań o charakterze randek.

Tabela 2. Mechanizmy sygnalizacji nieświadomej w komunikacji.

\begin{tabular}{|l|l|l|}
\hline Rodzaj sygnałów & $\begin{array}{l}\text { Rodzaj } \\
\text { przekazywanej } \\
\text { treści }\end{array}$ & $\begin{array}{l}\text { Struktury mózgu } \\
\text { związane z danym } \\
\text { systemem } \\
\text { sygnalizacyjnym }\end{array}$ \\
\hline 1. Aktywność & Zainteresowanie & $\begin{array}{l}\text { Autonomiczny układ } \\
\text { nerwowy }\end{array}$ \\
\hline 2. Wpływ & $\begin{array}{l}\text { Uwaga (mechanizmy } \\
\text { uwagowe i } \\
\text { orientacyjne) }\end{array}$ & $\begin{array}{l}\text { Struktury podkorowe } \\
\text { skupione wokół } \\
\text { pokrywy śródmózgowia } \\
\text { (wzgórki górne) }\end{array}$ \\
\hline $\begin{array}{l}\text { 3. Synchronia } \\
\text { (mimikra) }\end{array}$ & Empatia & Neurony lustrzane \\
\hline 4. Spójność (płynność) & $\begin{array}{l}\text { Kompetencja, } \\
\text { profesjonalizm }\end{array}$ & $\begin{array}{l}\text { Móżdżek i jądra } \\
\text { podstawy }\end{array}$ \\
\hline
\end{tabular}

Teza o nieświadomości jest również bardzo ważna w modelach wpływu społecznego w ramach psychologii społecznej. Na uwagę zasługują zwłaszcza dwa: model prawdopodobieństwa „rozpracowywania” informacji Petty'ego i Cacioppo i model systematyczno-heurystycznego przetwarzania Eagly i Chaiken (za: Aronson i inni 1997:320; zob. Tokarz 2006:229). Oba modele zasadzają się na przekonaniu, że istnieją dwa tryby przetwarzania informacji: tryb systematyczny i tryb heurystyczny. Co za tym idzie, można wyróżnić dwie drogi wzajemnego oddziaływania na siebie w komunikacji: drogę centralną i obwodową. Ustalenia te ilustruje tab. 3 .

Tabela 3. Modele podwójnego przetwarzania w psychologii perswazji.

\begin{tabular}{|l|l|l|}
\hline & Droga centralna & Droga obwodowa \\
\hline Narzędzie wpływu: & $\begin{array}{l}\text { Argumenty (fakty, } \\
\text { dowody) }\end{array}$ & $\begin{array}{l}\text { Sygnały (cues) np. } \\
\text { atrakcyjności, } \\
\text { profesjonalizmu }\end{array}$ \\
\hline $\begin{array}{l}\text { Tryb przetwarzania } \\
\text { informacji: }\end{array}$ & $\begin{array}{l}\text { Systematyczny - } \\
\text { uważne }\end{array}$ & $\begin{array}{l}\text { Heurystyczny - } \\
\text { uproszczony, }\end{array}$ \\
\hline
\end{tabular}




\begin{tabular}{|l|l|l|}
\hline & przemyśliwanie danych & $\begin{array}{l}\text { bezwysiłkowy, } \\
\text { mechaniczny }\end{array}$ \\
\hline Rodzaj reakcji: & Przemyślana & Automatyczna \\
\hline
\end{tabular}

\subsection{Nie postrzegamy rzeczy takimi jakimi są; postrzegamy je zależnie od tego, kim jesteśmy}

Dość powszechnym obecnie w humanistyce poglądem jest konstruktywizm (Skibiński 2003). Zgodnie $\mathrm{z}$ nim ten sam obiekt może być umysłowo reprezentowany na wiele różnych sposobów, w zależności od nastawienia, kontekstu, wcześniej nabytej wiedzy, oczekiwania, stanu motywacyjnego, nastroju lub emocji, wreszcie trwałych wymiarów intelektu i osobowości (Nęcka, Orzechowski, Szymura 2006:61). Oznacza to, że każdy samodzielnie i aktywnie konstruuje swoją mapę (model) rzeczywistości. Innymi słowy, człowiek jest istotą tworzącą modele świata. A zatem ludzie nie reagują na rzeczy w świecie, ale na swoje wyobrażenia o tych rzeczach. Albo jak to ujmuje Stewart: ludzie żyja nie $w$ świecie rzeczy, ale $w$ świecie znaczeń. Nie reagujemy ani na przedmioty, ani na ludzi, ale na to, co one dla nas znacza (Stewart 2007:187). Nasze konstrukty dotyczą sytuacji interakcyjnych, w jakich się znajdujemy, osób, z którymi się spotykamy, definiujemy też relacje między nami a interlokutorami oraz oczywiście naszą rolę (zob. Trenholm, Jensen 1992 w: Stewart 2007:202). Zdolność ta niesie ze sobą ewidentne korzyści (szybkość orientowania się w świecie, identyfikowania osób i obiektów w otoczeniu, decydowania itd.), jest też jednak obarczona pewnymi kosztami w formie różnych iluzji i uproszczeń, których padamy ofiarą (zob. Tyszka 2000; Aronson i inni 1997:123).

Założenie konstruktywistyczne przyjmowane jest m.in. w psychologii społecznej, psychologii poznawczej, w lingwistyce kognitywnej i szeroko pojmowanych naukach kognitywnych, a także w programowaniu neurolingwistycznym. W ramach NLP można je uznać za najważniejsze (zob. O'Connor 2001:5).

$\mathrm{Na}$ gruncie badań nad komunikacją podnosi się kwestię tego, w jaki sposób możliwe jest uzyskanie porozumienia, skoro wchodzący w interakcje interlokutorzy dysponują odrębnymi, zindywidualizowanymi modelami świata. Żuk (2001) przypomina, że skoro konwersacja jest procesem uzgadniania znaczenia, to jednym $\mathrm{z}$ podstawowych wyznaczników, które określają jej skuteczność, jest zjawisko rozumienia. Jednak podstawową barierą na drodze do wzajemnego zrozumienia (i dalej porozumienia) jest inność mentalnych światów komunikujących się osób. Narzędziem służącym rozjaśnianiu znaczeń wypowiedzi interlokutorów jest tzw. metamodel, czyli zbiór pytań pozwalających zrekonstruować treści założone, usunięte, zgeneralizowane itp. Przyjmując za Awdiejewem (2004), że każda wypowiedź w języku naturalnym jest jedynie bodźcem do inferencji dla odbiorcy, można stwierdzić, że potencjalnie z każdym komunikatem wiąże się ryzyko nieporozumienia. Oczywiście im bardziej 
przekazywana treść jest złożona i abstrakcyjna, tym trudniejszy jej odbiór. $\mathrm{W}$ związku $\mathrm{z}$ tym, drugim preskryptywnym modelem komunikacji postulowanym przez różnych autorów (Rosenberg 2003; Schulz von Thun 2007a; Fanning i inni 2001; Jarlnaes, Marcher 2004) jest model komunikatu pełnego. Istotą tego modelu jest uwzględnianie opisu faktów i oddzielanie go od własnych interpretacji tych faktów. Precyzowanie odniesień własnych stanów mentalnych (myśli, uczuć, pragnień) służy rzeczowej i zrozumiałej komunikacji, a co za tym idzie zapobieganiu niezrozumieniu.

\subsection{Umysł człowieka jest ucieleśniony}

Procesy poznawcze, świadomość, inteligencja są ukształtowane przez ciało człowieka (Pfeifer, Bongard 2007; Gärdenfors 2010; Wilson 2002; Casacuberta 2007). Współczesna humanistyka przeciwstawia się dualizmowi kartezjańskiemu. Fogel (2009:29) pisze: „I feel, therefore I am”, Gärdenfors (2010:47) stwierdza: „Sentio, ergo sum”. Warto zaznaczyć, że ideę ucieleśnionego poznania głoszono już wcześniej. Przykładowo już Freud pisał w „Ego i id”: „... the conscious ego: that it is first and foremost a body-ego" (za: Cameron 2002:237), a William James w „The Principles of Psychology” (1950:291 za: Cameron 2002:237) pytał: „... our bodies themselves, are they simply ours, or are they us?”. Niemal wiek później czołowi psychoterapeuci somatyczni, bazując na licznych obserwacjach z praktyki terapeutycznej, odpowiedzieli na to pytanie zdecydowanie twierdząco. Lowen w „Bioenergetics” (1975:54) stwierdzil: „You are Your Body“, a Kurtz i Prestera w „The Body Reveals” (1976:ix) napisali: „... the body reveals the person; it is the person”. W jednej z nielicznych monografii poświęconych interocepcji - „Visceral Sensory Neuroscience” - Cameron postuluje: „Visceral awareness is a component of a larger awareness, a larger sense, an awareness of the „I”, or the „me”. The „" is usually not thought of as essentially a bodily awareness” (Cameron 2002:205).

Sprawą oczywistą jest, że mózg kontroluje nasze ciało zarówno na poziomie świadomym, jak i nieświadomym. Psychosomatyka zebrała liczne dowody na to, że nasz umysł wpływa na nasze ciało, często wpływając na stan naszego zdrowia. Mniej oczywiste jest to, że ciało (zarówno morfologia, materialne własności, jak i ustawienie i ruch) może wpływać na umysł, nasze emocje, fizjologię i zachowanie (zob. Carney, Cuddy, Yap 2010). Co więcej, idea ucieleśnienia rozumiana jest na kilka różnych sposobów (zob. Wilson 2002). W kontekście komunikacji międzyludzkiej, a zwłaszcza komunikacji językowej, szczególnie ważne jest założenie o doświadczeniowym pochodzeniu naszego systemu pojęciowego (tzw. eksperiencjalizm). Lakoff i Nunez (2000) przekonywująco udowadniają, że abstrakcyjne pojęcia, np. z matematyki, są możliwe do pomyślenia tylko dzięki metaforom, które odnoszą te pojęcia do naszych doświadczeń. Ustalenie to wspiera wspomnianą wyżej koncepcję komunikatu pełnego, która postuluje odwoływanie się w swych przekazach do doświadczeń zmysłowych. 
Z pewnością związek mózgu (umysłu) i ciała najlepiej opisuje podejście interakcyjne, które uwzględnia wzajemne oddziaływanie jednego na drugie. $W$ badaniach nad komunikacją istotne jest dostrzeżenie tej możliwości, że nasze ciała oddziałują na nasze umysły, a także na ciała (i przez to na umysły) innych. O komunikacji ciała-z-ciałem świadczą opisane wyżej formy mimikry motorycznej. Można przypuszczać, że ta perspektywa pozwoli wyjaśnić wiele nieuchwytnych dotąd aspektów komunikacji. Wskazane wyżej takie zjawiska komunikacyjne, jak sympatia, charyzma, a także antypatia czy wrogość mogą doczekać się wnikliwych opisów i wyjaśnień.

Podsumowując, zauważmy, że przedstawione wyżej tezy wzajemnie się wspierają, tworząc spójny obraz człowieka - istoty o silnym instynkcie stadnym, nastawionej na innych, a przez to też emocjonalnej, targanej wewnętrznymi sprzecznościami, aktywnie konstruującej swoje wewnętrzne modele rzeczywistości i podlegającej nieświadomym procesom psychicznym ugruntowanym w jej cielesności. A zatem wizja ta wyraźnie zaprzecza takiej koncepcji człowieka, zgodnie z którą jest on istotą racjonalną, zainteresowaną tworzeniem logicznego i ścisłego obrazu świata, świadomą, wewnętrznie jednolitą, uporządkowaną czy wręcz zintegrowaną, niezależną od swojej cielesności i wpływu otoczenia.

\section{O znaczeniu ciała w komunikacji}

W świetle wyżej wymienionych twierdzeń rola ciała w komunikacji nabiera szczególnego znaczenia. Przemawiają za tym następujące argumenty:

$>$ język ciała odgrywa kluczową rolę $\mathrm{w}$ regulowaniu relacji międzyludzkich (zob. Aronson, Wilson i Akert 1997; Leathers 2007:22);

> kłamstwo, będące wynikiem wewnętrznych sprzeczności, znajduje wyraz na poziomie komunikacji niewerbalnej (Ekman 2007); Aronson i współpracownicy (1997:176) zauważają, że często ujawniamy mieszaninę emocji;

$>$ istnieje powszechna zgoda co do tego, że nasze emocje znajdują wyraz przede wszystkim w języku ciała (Mehrabian 1971, Argyle 2002; Ekman 2007);

nasz język ciała jest w przeważającej mierze wyrazem naszych nieświadomych procesów mentalnych (Argyle 2002).

We współczesnych badaniach nad komunikacją rola ciała została podkreślona przede wszystkim przez Mehrabiania, którego badania pozwoliły wyciągnąć wniosek, iż w przekazie postaw emocjonalnych główną rolę odgrywa ton głosu i język ciała (zob. Mehrabian 1971).22 Wyniki te potwierdzone zostały w eksperymencie Argyle'a (zob. Kurcz 2000:195-196). Jakkolwiek badania te są bodaj najczęściej cytowanymi w omawianym tutaj kontekście, warto przypomnieć również niezwykle

${ }^{22}$ Kurcz (2000:195-197) dokonuje krótkiego przeglądu badań nad rolą składnika werbalnego i niewerbalnego w interpretacji ogólnego znaczenia przekazu. Zob. również Leathers 2007:20. 
ważne prace badawcze Rosenthala nad tzw. „efektem Pigmaliona” (zwanym również „efektem Rosethala”). Rosenthal w serii różnych eksperymentów wykazał, że oczekiwania ludzi (np. nauczycieli, eksperymentatorów, lekarzy, zwierzchników w pracy) wobec swoich partnerów interakcyjnych (np. uczniów, badanych, pacjentów, pracowników) wpływają na ich zachowania. Kurcz (2000), referując badania Rosenthala nad „efektem eksperymentatora w badaniach nad zachowaniem się", stwierdza, że ciągle jeszcze nie wiadomo dokładnie, jak te oczekiwania eksperymentator komunikuje badanym. Należy zaznaczyć, że chodzi tu o bardziej subtelny poziom oddziaływania niewerbalnego niż ten, który badali Mehrabian czy Argyle (zob. Kurcz 2000:196-197).

W literaturze poświęconej komunikacji interpersonalnej w różny sposób uzasadniana była rola języka ciała i tzw. komunikacji niewerbalnej. Oto kilka argumentów, które warto w tym miejscu przywołać:

$>$ język ciała w sposób oczywisty oddziałuje na zmysł wzroku, tymczasem układ wzrokowy dostarcza człowiekowi ok. 80\% informacji o świecie zewnętrznym (zob. Wróbel 2001); znajduje to odzwierciedlenie w powiedzeniu „obraz jest wart tyle, co tysiąc słów";

> informacje przekazywane językiem ciała uznawane są za bardziej wiarygodne, co można tłumaczyć niskim stopniem kontrolowalności tego środka ekspresji (zob. hierarchia kontrolowalności - Kurcz 2000); co za tym idzie, łatwiej wyrażać kłamstwo werbalnie niż niewerbalnie, gdyż nad ciałem trudno zapanować;

$>$ język ciała jest starszy ewolucyjnie od języka werbalnego, a zatem nasze zachowania są bardziej zdeterminowane przez ten pierwszy niż przez ten drugi (zob. Załazińska 2002);

$>$ przeważnie jesteśmy $\mathrm{w}$ ciałosferze, a incydentalnie w słowosferze (Grove 2007).

Kultura Zachodu od czasów starożytności promuje rozum i słowo. Konsekwencją tego podejścia jest ignorowanie wszystkiego, co cielesne (por. Lowen 1992, Boadella 1992, Reich 1990). Podobne podejście zdaje się być widoczne również w niektórych koncepcjach komunikacji i badaniach nad komunikacją (por. Wendland 2008). Widoczne jest ono na przykład w językoznawczym nurcie badań nad komunikacją (pragmalingwistyka, analiza dyskursu, teoria aktów mowy), w którym porozumiewanie się międzyludzkie sprowadzane jest zasadniczo do językowego (werbalnego). W podejściu takim język ciała traktowany jest co najwyżej jako „dodatek” do słów, jako uzupełnienie przekazu werbalnego. Komunikację postrzega się tutaj jako proces wymiany informacji lub wypracowywania znaczeń, który odbywa się przede wszystkim za pomocą języka werbalnego, natomiast pomija się wpływ języka niewerbalnego na cały proces i interlokutorów w nim uczestniczących lub wręcz się go nie docenia. Podejście to można uznać za efekt ewolucji myśli nad komunikacją wśród semiotyków i językoznawców starających się zobiektywizować swój przedmiot badawczy. Warto też przypomnieć, że ogromny wpływ na 
językoznawstwo i teorię komunikacji wywarla perspektywa cybernetyczna i matematyczna, zwłaszcza model Shannona i Weavera, która uniemożliwiła badanie języka ciała $\mathrm{w}$ interakcjach między ludźmi. Tymczasem nowe badania neurobiologii społecznej (zob. Goleman 2007) pozwalają wysunąc tezę, że to właśnie ciało odgrywa główną rolę w komunikacji, gdyż jest stymulatorem emocji i procesów poznawczych oraz głównym czynnikiem wpływającym na przebieg interakcji. Możemy tu mówić o podświadomej interakcji, „niewerbalnym tańcu” (Goleman 2007), oddziaływaniu ciała na ciało, komunikacji z „nieświadomości do nieświadomości” (Mayer 1996), „konwersacji limbicznych systemów” nadawcy i odbiorcy (Buck 1994 za: Ohme 2003), komunikacji typu „mózgmózg" (Ingram 1994 za: Ohme 2003). To wszystko każe stwierdzić, że żyjemy cały czas przede wszystkim w „ciałosferze”, a jedynie od czasu do czasu w logosferze. Warto w tym miejscu przywołać obserwację Grove'a (2007:125): $W$ dziatania niewerbalne jesteśmy $w$ toku konwersacji zaangażowani bez przerwy - $w$ równym stopniu, kiedy nie mówimy i kiedy mówimy. (...) Każda ze stron konwersacji jest zatem nieprzerwanie zaangażowana $w$ zachowanie niewerbalne, bez względu na to, czy mówi, czy stucha wypowiedzi drugiej osoby.

Wyłania się z tego perspektywa komunikacji, którą można by określić somatyczną. Perspektywa ta nie tyle zaprzecza koncepcjom redukującym komunikację jedynie do językowej (werbalnej) czy stanowiskom, które ostrożnie uwzględniają komunikację niewerbalną (cielesną) jako „dodatek“ do werbalnej, ale bardziej eksponuje ją $\mathrm{w}$ przestrzeni komunikacji międzyludzkiej. Stanowi ona więc alternatywę wobec werbocentrycznej wizji komunikacji.

\section{O potrzebie oddzielenia komunikacyjnie nastawionych sygnałów od symptomów odzwierciedlających stany wewnętrzne}

Uwzględnienie języka ciała $\mathrm{w}$ przestrzeni komunikacyjnej wiąże się z pewnymi problemami natury teoretycznej. Szczególnie ważne jest ustalenie, $w$ jakich terminach powinno się rozpatrywać zarówno elementy tego języka (ekspresje), jak i to, do czego się one odnoszą (czego są wyrazem). Zacznijmy od omówienia tej drugiej kwestii. Rozpatrując komunikację $\mathrm{w}$ perspektywie werbocentrycznej, łatwo dokonać prostego przeniesienia $\mathrm{w}$ domenę komunikacji niewerbalnej takich pojęć, jak „wiedza”, „znaczenie”, „sens”, „dane”, „treśc”, „myśl”, „pojęcia” itp. Zauważmy, że są one wykorzystywane $\mathrm{w}$ odniesieniu do komunikacji znakowej czy symbolicznej. Wszystkie one z definicji odnoszą się do stanów intencjonalnych (tj. są o czymś) i mają charakter reprezentacyjny. $\mathrm{W}$ tym sensie mogą być np. o emocjach. Jest jednak istotna różnica między myśleniem o emocjach a przeżywaniem emocji, podobnie jak jest różnica między komunikowaniem emocji a ich wyrażaniem, między „referowaniem” a ekspresją, między robieniem a byciem. Warto tu 
podkreślić obiektywizujący charakter komunikacji23 i podmiotowy ekspresji. Mowa tutaj zatem o niebezpieczeństwie sprowadzania komunikacji jedynie do takiej, w której przekazywane są stany stricte poznawcze (wspomnienia, wyobrażenia, spostrzeżenia, sądy, przekonania, poglądy, idee itd.). Istotne jest więc dokonanie rozróżnienia na:

$>$ „stany subiektywne” (informacja egocentryczna) - stany fizjologiczne, afektywne lub psycho-fizyczne,

$>$ "stany obiektywizujące” (informacja allocentryczna) reprezentujące stany rzeczy 24 .

Rzecz w tym, by odróżnić komunikację z pośredniczącą funkcją myśli od bezpośredniej komunikacji (czy też może ekspresji) stanów organizmu (doznań, nastrojów, emocji, postaw, nastawień itd). Korzystając z tego rozróżnienia, można zaproponować, by traktować język werbalny jako odnoszący się do stanów obiektywizujących, natomiast język ciała jako odnoszący się przede wszystkim do stanów subiektywnych. Pozostaje jednak kwestia określenia charakteru zewnętrznego wyrazu tych stanów subiektywnych. Rozwiązania dostarcza tutaj semiotyka. Zaznaczmy na wstępie, że bodaj najstarszy i najważniejszy problem w refleksji semiotycznej dotyczy podziału na znaki naturalne i sztuczne (konwencjonalne, umowne) (zob. Pelc 1982, Kowzan 1998, Podsiad 2000, Cobley i Jansz 1999). Warto w tym miejscu przypomnieć, że semiotyka jako nauka o znakach wyrosła z badań pierwszych lekarzy świata zachodniego, których interesowały cielesne symptomy chorobowe (Sebeok 1994:xi). A zatem poprzedniczka współczesnej semiotyki zainteresowana była wyłącznie znakami naturalnymi. Poza tym istotne jest również, by zaznaczyć, że w myśli semiotycznej wśród głównych pojęć odnoszących się do jej przedmiotu badawczego wyróżnia się nie tylko „znak”, ale również „oznaka”, „Ślad”, „symptom”, „sygnał”, „symbol”, „wskaźnik”, „ikona” (zob. Pelc 1982; Sebeok 1994; Barthes 2009). Kategorie te dzieli się i przeciwstawia sobie ze względu na ich „naturalność” lub „konwencjonalność”. Przede wszystkim odróżnia się oznaki od znaków (a także symptomy od sygnałów) (Ziembiński 2000; Pelc 1982; Guiraud 1974). Nie wnikając w szczegóły tych rozważań, poprzestańmy na następujących wyjaśnieniach. Znak jest czymś, co zastępuje coś, zawsze ze względu na kogoś. A zatem jest on związany $\mathrm{z}$ zachowaniem uświadomionym i komunikacyjnym. Natomiast oznaka (czy też symptom) powstaje niezależnie od obserwatora (uczestnika) interakcji, a także od

23 Fleischer (2007:10-11) pisze tak: Cokolwiek teraz powiem, muszę, skoro chcę coś powiedzieć, rozpocząć lub właśnie rozpocząłem jakimś obiektem. Kiedy rozpoczyna się komunikacja, powstaje tym samym obiekt i jest odtąd obecny. (...) jeśli się mówi, mówić można właśnie wyłącznie o czymś. Jednak nie dlatego, że owo coś istnieje lub nie istnieje (...) lecz jedynie dlatego, że język i komunikacja wytworzone są tak, iż bez owego czegoś, bez obiektu, nie można się obejść.

${ }_{24}$ Warto w tym miejscu przypomnieć ustalenia w ramach fenomenologii, że każde przeżycie (akt mentalny) ma nie tylko stronę intencjonalną (przedmiotową), ale również subiektywną (podmiotową). 
samego nadawcy (choć w tym wypadku termin „nadawca” zdaje się być nieprzystający), a zatem jest nieświadoma i nie ma charakteru komunikacyjnego. Innymi słowy, (o)znaki cielesne mogą być: (1) intencjonalne, świadome, wysyłane celowo lub (2) nieintencjonalne, nieświadome i przekazywane niecelowo ${ }^{25}$. Naturalnie granice podziału są tu płynne, gdyż to, co funkcjonuje zasadniczo jako oznaka (lub symptom) może zostać świadomie wykorzystane jako znak (np. pierwotnie naturalna, nieświadoma ekspresja danej emocji na twarzy może być uświadomiona i powtórzona $\mathrm{w}$ celach komunikacyjnych, jak często bywa $\mathrm{np}$. $\mathrm{z}$ uśmiechem). Można tę zależność przedstawić graficznie w formie strzałki, która reprezentuje przejście od oznak nieświadomych i nieintencjonalnych do znaków świadomych i intencjonalnych (zob. rys.3).

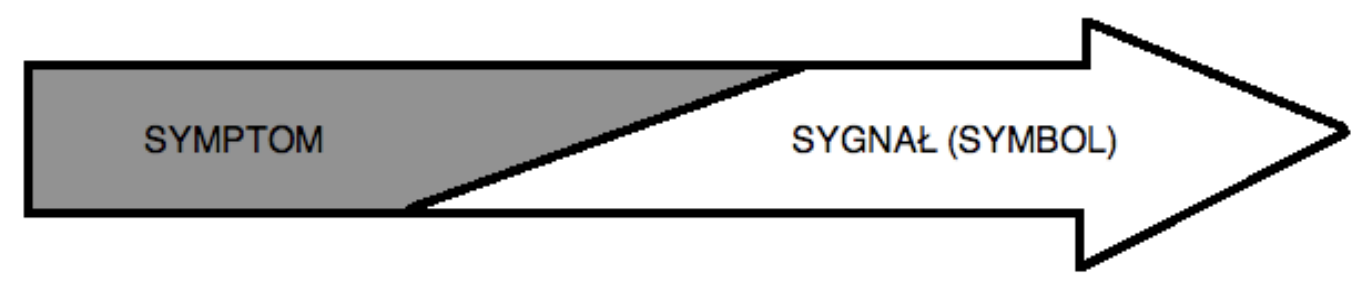

Rys.3. Ewolucja znaków - od nieświadomych do świadomych.

W refleksji nad językiem ciała i komunikacją niewerbalną powyższy podział można uznać za szczególnie istotny. Jak zauważa Grove (w: Stewart 2007:125):

zachowania niewerbalne jednostki wytwarzane są raczej bez udziału myśli, a więc $\mathrm{w}$ porównaniu $\mathrm{z}$ bardziej świadomie wybieranymi zachowaniami werbalnymi, pozostają $\mathrm{w}$ znacznym stopniu poza świadomością zachowania.

A zatem ich pierwotna natura ma charakter oznakowy, symptomatyczny, a nie stricte znakowy czy symboliczny. Należy pamiętać, że język ciała składa się przede wszystkim ze znaków naturalnych, a nie sztucznych. Można się tutaj pokusić o stwierdzenie, że podczas gdy język werbalny związany jest bardziej z działaniem (komunikacyjnym), tak język ciała jest bardziej wyrazem bycia (czy też sposobem bycia) ${ }^{26}$. Zdając

${ }_{25}$ Zob. również: podział Guiraud (1974) na rozumienie i odczuwanie jako dwa główne tryby postrzegania i (co za tym idzie) oznaczania i odpowiadające im znaki logiczne i znaki ekspresywne.

26 Por. Lowen (1992:14): „Jesteś swoim ciałem. (...) Nie można istnieć w oderwaniu od żywego ciała, w którym się bytuje i poprzez które wyraża się siebie i utrzymuje kontakty z otaczającym światem. (...) Jesteś swoim ciałem, a twoje ciało jest tobą, a więc wyraża kim jesteś, jest twoim sposobem bycia w świecie.“ (podkreślenie - W.L.) 
sobie sprawę $\mathrm{z}$ faktu, iż ekspresja niewerbalna może mieć dwojaki charakter, badacz języka ciała może chcieć zawęzić swoje badania do jedynie znaków komunikacyjnych przekazujących jakieś konkretne znaczenia i jednocześnie pominąć te znaki, które nie mają charakteru komunikacyjnego, są raczej nieuświadomione i nieintencjonalne. Podejście takie jednak ignoruje ustalenia dotyczące natury samej komunikacji, jak i uwarunkowań psychologicznych komunikujących się ludzi. Tymczasem coraz więcej badań (zob. wcześniej - Ohme, Pentland) pozwala postawić tezę, że zachowania nie-komunikacyjne mogą mieć większy wpływ na komunikację niż zachowania stricte komunikacyjne. Innymi słowy, przejawy bycia silniej oddziałują na innych niż wyrazy działania. Można to też sformułować następująco - to, co nieświadome, przeważa w komunikacji nad tym, co świadome.

Krupska-Perek (2001:155) przytacza, za Marianne Gullberg, dwie definicje gestów - standardową i naukową:

$>$ pierwsza wskazuje na to, że gesty wyrażają i uwydatniają zawartość myślową i emocjonalną wypowiedzi,

$>$ druga odrzuca ruchy nie wchodzące zasadniczo w skład aktu komunikacji, ale dające się interpretować jako zachowania informujące o nadawcy - tzw. samoregulatory (np. układ ciała w pozycji siedzącej lub stojącej, kręcenie kciukami itp.).

Następnie autorka koncentruje się na tych z pierwszej grupy, czyli na gestach komunikacyjnych. Taka perspektywa jest charakterystyczna dla badań językoznawczych zorientowanych na analizę przekazywanych i odbieranych informacji (znaczeń). Istotne jest, by tutaj zaznaczyć, że w przekazie informacji (znaczeń) w dialogu potocznym, a tym bardziej zadaniowym, język ciała (czy szerzej - niewerbalny) nie zastępuje języka werbalnego (ma to miejsce w przypadku komunikacji osób głuchoniemych). Zasadniczo jego funkcja tutaj ogranicza się do wspomagania komunikatów wysyłanych werbalnie. Chodzi tu o emblematy, regulatory konwersacji i ilustratory27. A zatem możemy tutaj mówić o zasadniczo wtórnej funkcji języka ciała, który jako środek językowy wchodzi niejako na "teren zadan” pierwotnie realizowanych przez słowa (to w przypadku języka słownego uznaje się, że główną funkcją, jaką on pełni, jest odzwierciedlanie rzeczywistości). Wciąż jednak ekspresja nieuświadomiona i nie-komunikacyjna pozostaje tutaj $\mathrm{w}$ tle badań, zupełnie niewidoczna dla badacza zainteresowanego jedynie przekazywaniem treści $\mathrm{w}$ procesie porozumiewania się między ludźmi. Istotne jest zatem wprowadzenie rozdzielenia na trzy rodzaje języków obecnych w interakcjach:

$>$ język werbalny - służy wyrażaniu myśli, informacji;

$>$ język ko-werbalny - pomaga w klaryfikowaniu myśli za pomoca środków pozasłownych; pełni funkcję podrzędną, pomocniczą w stosunku do języka werbalnego;

${ }_{27}$ Zauważmy przy tym, że są to gesty najbardziej kulturowo uwarunkowane. 
$>$ język niewerbalny - jest wyrazem stanów psycho-fizycznych jednostki, a zatem nie służy komunikacji, gdyż nie jest „produkowany“ intencjonalnie i świadomie.

Językiem niewerbalnym, rozumianym $\mathrm{w}$ taki sposób, jak przedstawiony powyżej, zajmuje się psychologia i psychoterapia somatyczna, a także medycyna psychosomatyczna. Tutaj język ciała traktowany jest jako sposób odzwierciedlania stanu psychicznego i fizycznego (jest oznaką zdrowia, oznaką dominującego stanu wewnętrznego, charakteru, itd.). Tutaj mówi się również o symptomach fizjologicznych, takich jak np. zmiana tętna, ciśnienie krwi, rytm oddychania, pocenie się, zmiana koloru skóry, rozszerzanie się źrenic, pewne formy mrugania (zob. Barratt 2010; Totton 2005; Totton 2003).

\section{Metafora góry lodowej w komunikacji}

Przedstawione powyżej ustalenia zarówno te dotyczące funkcjonowania istot komunikujących się, jak i samej komunikacji międzyludzkiej, pozwalają nakreślić taki obraz naszego porozumiewania się, który odwołuje się do starej metafory zaproponowanej jeszcze przez Freuda metafory góry lodowej. Metafora ta była dotychczas wykorzystywana $\mathrm{w}$ opisie jednostki, a nie człowieka, jako istoty interakcyjnej. Powołując się na przedstawione wyżej ustalenia, można pokusić się o przeniesienie tej metafory w domenę badań nad komunikacją.

Skoro człowiek jest istotą, której zachowaniem w dużej mierze rządzą nieświadome mechanizmy poznawcze, motoryczne i emocjonalne, to interakcję międzyludzką można opisać jako przebiegającą na dwóch poziomach:

$>$ poziom jawny - werbalny, świadomy, racjonalny, treściowy,

$>$ poziom ukryty - niewerbalny, podświadomy, emocjonalny, relacyjny.

Granice oczywiście są tu płynne, podobnie jak stosunek świadomości do nieświadomości w koncepcji metafory góry lodowej w psychoanalizie i omówiony w pkt.7 podział na znaki i oznaki. Ilustruje to rys. 4. 


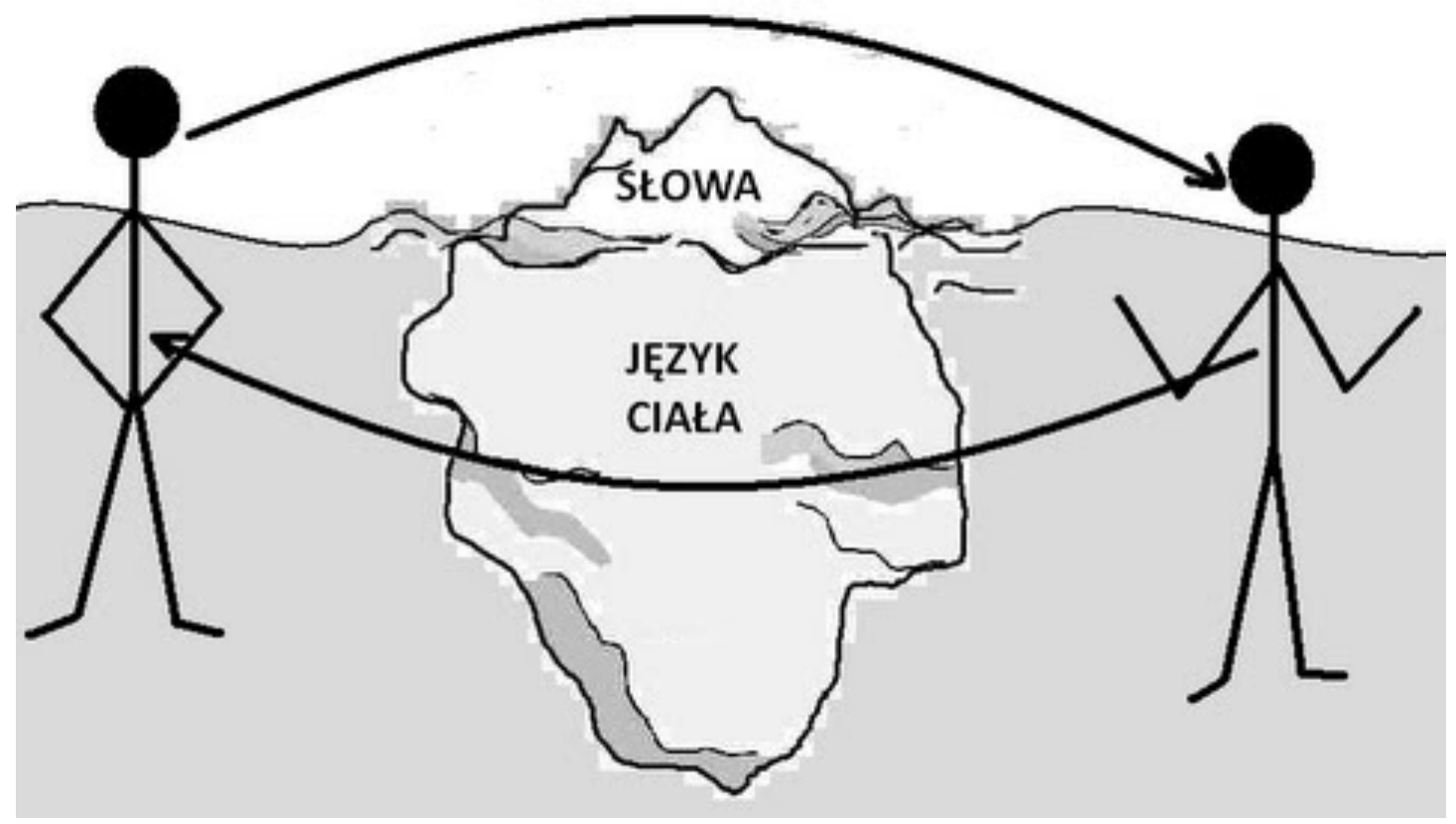

Rys. 4. Graficzna prezentacja metafory góry lodowej w komunikacji

Życie w logosferze i ignorowanie „ciałosfery” sprawia, że to, co jest cielesne, niewerbalne $\mathrm{i}$ nieświadome, rozpatrywane jest $\mathrm{w}$ terminach nieostrych czy wręcz magicznych - „to coś”, „aura”, „wibracje”, „urok osobisty” 28 , „fluidy”, natomiast głównym mechanizmem „odbioru” tych zjawisk zdaje się być intuicja. Jeśli uznać, że w procesie komunikacji zachodzi wiele procesów pozostających poza naszą świadomością, pozostają nam tylko przeczucia $\boldsymbol{i}$ uczucia - które zwerbalizowane pozostają niejasne („Nie wiem, w co mam wierzyć”, „Nie ufam mu”, „Coś tu nie gra”, „Jest jakiś inny(a)”, „On(a) ma to coś” itp.). Innymi słowy, interlokutorzy stale wysyłają jakieś potencjalne sygnały (będące de facto oznakami), a odbiorcy, odbierając je, pozostają pod ich wpływem, prawdopodobnie tworzą się $\mathrm{w}$ nich jakieś wrażenia i odczucia, a te, choć wymykają się precyzyjnej konceptualizacji, regulują ich zachowania i reakcje. Nie dość, że procesy te zachodzą nieświadomie, są one też bardzo szybkie. „Magia komunikacji”, której podłożem są znaki cielesne, z jednej strony czyni interakcję tajemniczą, czasem ekscytującą czy wręcz romantyczną, z drugiej - jest źródłem niepewności, niezrozumienia, frustracji czy wręcz konfliktów i nieporozumień. Tak czy inaczej, można stwierdzić, że w komunikacji twarzą w twarz drugi człowiek często jawi się jako zagadka. Badania również potwierdzają tę intuicję. Zdolności prawidłowego odczytywania mowy ciała są wbrew pozorom znikome

${ }^{28}$ Wyłania się tu przy okazji kolejna potrzeba w badaniach nad językiem ciała (czy szerzej - nad komunikacją), a mianowicie obiektyfikacja zjawisk natury psychologicznej. 
u większości ludzi, nawet u tych, po których można by się spodziewać pewnej wprawy (np. po policjantach) (zob. Ekman 2007).

W świetle dotychczasowych rozważań, znany aksjomat Watzlawicka „one cannot not communicate" nabiera nowego znaczenia. Otóż, jeśli uznać, że twierdzenie to odnosi się do przejawów bycia uczestników interakcji oraz przyjmując, że komunikacja ma zawsze nadawcę i odbiorcę i składa się z wymian informacji kierowanych do drugiej strony - wówczas należałoby uznać użyte przez Watzlawicka pojęcie „komunikacja” za sugestywne, acz nieodpowiednie. Należałoby zatem powiedzieć - „one cannot not be in communication", albowiem człowiek może odmawiać komunikacji z drugim człowiekiem, może „wyłączyć się”, ale nie może przestać być.

\section{Bibliografia}

Argyle, M. 1972. The Psychology of Interpersonal Behaviour. Penguin Books.

Argyle, M. 2002. Psychologia stosunków międzyludzkich. Warszawa: Wydawnictwo Naukowe PWN.

Aronson, E., Pratkanis, A. 2004. Wiek propagandy. Używanie i nadużywanie perswazji na co dzień. Warszawa: Wydawnictwo Naukowe PWN.

Aronson, E., Wilson, T.D., Akert, R.M. 1997. Psychologia spoteczna. Serce i umyst. Poznań: Wydawnictwo Zysk i Spólka.

Awdiejew, A. 2004. Gramatyka interakcji werbalnej. Kraków: Wydawnictwo Uniwersytetu Jagielońskiego.

Awdiejew, A., Habrajska G. 2004. Wprowadzenie do gramatyki komunikacyjnej, tom 1. Łask: Oficyna Wydawnicza LEKSEM.

Awdiejew, A., Habrajska G. 2006. Wprowadzenie do gramatyki komunikacyjnej, tom 2. Łask: Oficyna Wydawnicza LEKSEM.

Barratt, B.B. 2010. The Emergence of Somatic Psychology and Bodymind Therapy. Palgrave Macmillan.

Barthes, R. 2009. Podstawy semiologii. Kraków: Wydawnictwo Uniwersytetu Jagielońskiego.

Berne, E. 1999. Dzień Dobry i co dalej? Poznań: Rebis.

Bernhardt, P. 2004. Individuation, Mutual Connection, and the Body's Resources: An Interview with Lisbeth Marcher. w: Body, Breath \& Consciousness. A Somatic Anthology, Ian Macnaughton, Berkley California: North Atlantic Books.

Boadella, D. 1988. Przeniesienie, zakłócenie i rezonans. w: Rezonans $i$ Dialog. Zaktócenia kontaktu $w$ pomaganiu. Warszawa: Polskie Towarzystwo Psychologiczne (materiały szkoleniowe Laboratorium Psychoedukacji).

Boadella, D. 1992. Przeptywy życia. Wprowadzenie do biosyntezy. Warszawa: Jacek Santorski \& CO Agencja Wydawnicza.

Cameron, O.G. 2002. Visceral Sensory Neuroscience. Interoception. Oxford-New York: Oxford University Press.

Carney, D.R., Cuddy, A.J.C., Yap A.J. 2010. Power Posing: Brief Nonverbal Displays Affect Neuroendocrine Levels and Risk Tolerance. Research report. w: Psychological Science XX(X) 1-6.

Casacuberta, D. 2007 Umyst. Czym jest i jak działa.Warszawa: Świat Książki. 
Chartrand, T.L., Maddux, W.W., Lakin, J.L. 2005. Beyond the PerceptionBehavior Link: The Ubiquitous Utility and Motivational Moderators of Nonconscious Mimicry. w: Hassin, R.R., Uleman, J.S., Bargh J.A. (editors) 2005. The New Unconscious. Oxford-New York: Oxford University Press.

Cobley, P., Jansz, L. 1999. Introducing Semiotics. Icon Books UK, Totem Books USA.

Craig, R.T. 1999. Communication Theory as a Field. w: Communication Theory. 9(2), 119-161.

De Houwer, J., Hermans, D. 2010. Cognition \& Emotion. Reviews of Current Research and Theories. Hove and New York: Psychology Press, Taylor \& Francis Group.

Dijksterhuis, A., Aarts, H., Smith, P.K., 2005. The Power of the Subliminal: On Subliminal Persuasion and Other Potential Applications. w: Hassin, R.R., Uleman, J.S., Bargh J.A. (editors) 2005. The New Unconscious. Oxford-New York: Oxford University Press.

Dwyer, D. 2005. Bliskie relacje interpersonalne. Gdańsk: Gdańskie Wydawnictwo Psychologiczne.

Eichelberger, W. 1999. Zatrzymaj się. Warszawa: Wydawnictwo Czarna Owca.

Ekman, P. 2007. Kłamstwo i jego wykrywanie w biznesie, polityce, matżeństwie. Warszawa: Wydawnictwo Naukowe PWN.

Evans, V., Green, M. 2006. Cognitive Linguistics. An Introduction. Edinburgh University Press.

Fleischer, M. 2007. Ogólna teoria komunikacji. Wrocław: Wydawnictwo Uniwersytetu Wrocławskiego.

Fogel, A. 2009. The Psychophysiology of Self-Awareness. Rediscovering the Lost Art of Body Sense. New York-London: W.W. Norton.

Freud, S. 2010. Wstęp do psychoanalizy. Warszawa: Wydawnictwo Naukowe PWN.

Gärdenfors, P. 2010. Jak Homo stał się sapiens. O ewolucji myślenia. Warszawa: Wydawnictwo Czarna Owca.

Gendlin, E. 1981. Focusing. Bantam Books.

Goleman, D. 1997. Inteligencja emocjonalna. Poznań: Wydawnictwo Media Rodzina.

Goleman, D. 2007. Inteligencja społeczna. Poznań: Dom Wydawniczy REBIS.

Grove, T.G. 2007. Niewerbalne elementy interakcji, w: Mosty zamiast murów. Warszawa: PWN.

Guiraud, P. 1974. Semiologia. Warszawa: Wiedza Powszechna.

Herzyk, A. 2001. Nieświadomość percepcyjna, poznawcza i emocjonalna z perspektywy neuropsychologii klinicznej. w: Ohme, R.K., Jarymowicz, M., Reykowski, J. 2001. Automatyzmy $w$ procesach przetwarzania informacji. Warszawa: Wydawnictwo Instytutu Psychologii PAN Szkoła Wyższa Psychologii Społecznej.

Hogan, K. 2001. Psychologia Perswazji. Warszawa: Wydawnictwo Jacek Santorski \& CO.

Jarlnaes E., Marcher L. 2004. The BodyKnot Model: A Tool for Personal Development, Communication, and Conflict resolution, w: Macnaughton, I. 2004. Body, Breath \& Consciousness. A Somatic Anthology. Berkley, California: North Atlantic Books.

Jaworski, A. 2006. Silence. w: Asher, R.E. (Editor-in-Chief) 1994. The Encyclopedia of Language and Linguistics. Pergamon Press, p. 377-378. 
Johnston, V.S. 1999. Why We Feel. The Science of Human Emotions. Cambridge, Massachuttes: Perseus Publishing.

Juszczyk, K. 2008. Komunikacja naturalna versus komunikacja wirtualna. Tom pokonferencyjny. Jezyk a multimedia-Dialog-konflikt. Wrocław: Wydawnictwo DSWE.

Kalat, J.W. 2011. Biologiczne podstawy psychologii. Warszawa: Wydawnictwo Naukowe PWN.

Kita, M. 2001. Język potoczny jako język bliskości. w: Habrajska, G. (red.) 2001. Język $w$ komunikacji. Łódź: Wydawnictwo Wyższej Szkoły HumanistycznoEkonomicznej w Łodzi. str. 170-175.

Kotarbiński, T. 2000. Traktat o dobrej robocie. Wrocław-Warszawa-Kraków: Zakład Narodowy im. Osslińskich Wydawnictwo Polskiej Akademii Nauk.

Kowzan, T. 1998. Znak i Teatr. Warszawa: Polskie Towarzystwo Semiotyczne.

Kozłowski, T. 2007. Kłamię, więc jestem. W poszukiwaniu początków samoświadomości. Taszów: Biblioteka Moderatora.

Krupska-Perek, A. 2001. Kod językowy a inne składniki aktu komunikacji bezpośredniej. w: Język $w$ komuniacji. Tom 1, Łódź: Wydawnictwo Wyższej Szkoły Humanistyczno-Ekonomicznej w Łodzi. str. 154-164

Kurcz, I. 2000. Psychologia języka i komunikacji. Warszawa: Wydawnictwo Naukowe „Scholar”.

Kurtz, R., Prestera, H. 1976. The Body Reveals. An Illustrated Guide to the Psychology of the Body. New York, San Francisco, London: Harper \& Row/Quicksilver Books, Publishers.

Lakoff, G., Núñez, R.E. 2000. Where Mathematics Comes From: How the Embodied Mind Brings Mathematics into Being.

Leathers, D.G. 2007. Komunikacja niewerbalna. Warszawa: Wydawnictwo Naukowe PWN.

LeDoux, J. 2000. Mózg emocjonalny. Tajemnicze podstawy życia emocjonalnego. Poznań: Media Rodzina.

Lowen A., 1992. Wstęp do bioenergetyki. Energia, język ciała, terapia. Warszawa: Jacek Santorski \& CO Agencja Wydawnicza.

Lowen, A. 1975. Bioenergetics. Penguin Compass.

Lowen, A. 2006. Duchowość ciata. Warszawa: Jacek Santorski \& CO Agencja Wydawnicza.

Macnaughton, I. 2004. Body, Breath \& Consciousness. A Somatic Anthology. Berkley, California: North Atlantic Books.

Mayer, R. 1996. Somatoterapia. Ciało w psychoterapii. Warszawa: Wydawnictwo Psychologii i Kultury Eneteia

McKay, M., Davis, M., Fanning, P. 2001. Sztuka skutecznego porozumiewania się. Gdańsk: Gdańskie Wydawnictwo Psychologiczne.

Mehrabian, A. 1971. Silent Messages. Belmont, California: Wadsworth Publishing Company, Inc.

Navarro, J. 2008. What Every Body is Saying. New York: Harper-Collins Publishers:

Nęcka, E., Orzechowski, J., Szymura, B. 2006. Psychologia poznawcza. Warszawa: Wydawnictwo Naukowe PWN i ACADEMICA Wydawnictwo SWPS

Nęcki, Z. 2000. Komunikacja mędzyludzka. Kraków: Oficyna Wydawnicza ANTYKWA.

O'Sullivan, M. 2005. Emotional Intelligence and Deception Detection: Why Most People Can't "Read" Others, But a Few Can. w: Applications of Nonverbal Communication. London: Lawrence Erlbaum Associates, Publishers. 
O'Connor, J. 2001. NLP Workbook. The Practical Guidebook to Achieving the Results You Want. London: Thorsons.

O’Connor, J., Seymour, J. 1996. Wprowadzenie do programowania neurolingwistycznego. Poznań: Zysk i S-ka.

Ohme, R.K. 2002. Homo Sapiens czy Homo Automaticus? w: M. Jarymowicz i R.K. Ohme. Natura Automatyzmów: Dyskusje interdyscyplinarne. Warszawa: Wydawnictwo IPPAN i SWPS. (s. 87-91)

Ohme, R.K. 2003. Tajemnice mikroekspresji, [w:] R.K. Ohme i M. Jarymowicz (red.), Automatyzmy $w$ regulacji psychicznej. Nowe perspektywy, (s. 97-107). Warszawa: Wydawnictwo IP PAN i SWPS.

Parkinson, B., Colman, A.M. 1999. Emocje i motywacja. Poznań: Zysk i S-ka Wydawnictwo.

Pease, B., Pease, A. 2004. The Definitive Book of Body Language. Buderim, Australia: Pease International

Pelc, J. 1982. Wstęp do semiotyki. Warszawa: Wiedza Powszechna

Pentland, A. 2008. Honest Signals. How They Shape Our World. Cambridge: MIT Press.

Pfeifer, R., Bongard, J. 2007. How The Body Shapes The Way We Think. A New View of Intelligence. Cambridge, Massachuttes, London, England: A Bradford Book, The MIT Press.

Podsiad, A. 2000. Stownik terminów i pojęć filozoficznych. Warszawa: Instytut Wydawniczy Pax.

Reich, W. 1990. Character Analysis. 3rd, enl. ed. New York: Noonday Press.

Rogoll, R. 1989. Aby być soba. Warszawa: Państwo Wydawnictwo Naukowe.

Rosenberg, M.B. 2003. Porozumienie bez przemocy. O języku serca. Warszawa: Jacek Santorski \& CO Agencja Wydawnicza:

Rust, S. 2010. Tańcowała żyrafa z szakalem. Cztery kroki empatycznej komunikacji. Warszawa: Wydawnictwo Czarna Owca.

Sarnowska, K., Dąbrowski, P., Pastuszka, T., Wieczorek, K. 2006. Kłamstwo $w$ białych rękawiczkach. Charaktery 11 (118) Listopad.

Schulz von Thun, F. 2007a. Sztuka rozmawiania. Analiza zaburzeń. Część 1. Kraków: Wydawnictwo WAM.

Schulz von Thun, F. 2007b. Sztuka rozmawiania. Style komunikacji. Część 2. Wydawnictwo. Kraków: Wydawnictwo WAM.

Schulz von Thun, F. 2007c. Sztuka rozmawiania. Dialog wewnętrzny. Część 3. Wydawnictwo. Kraków: Wydawnictwo WAM.

Sebeok, T.A. 1994. An Introduction to Semiotics. London: Pinter Publishers.

Skibiński, A. 2003. Homo Significus. Autorozprawa o poznaniu-języku. Warszawa: IMEX-GRAF Sp. z o.o.

Skudrzyk, A. 2005. Czy zmierzch kultuy pisma? O synestezji i analfabetyzmie funkcjonalnym. Katowice:Wydawnictwo Uniwersytetu Śląskiego.

Stewart, J. 2007. Mosty zamiast murów. Warszawa: Wydawnictwo Naukowe PWN.

Strelau, J. (red. nacz.) 2000. Psychologia. Podręcznik akademicki. Gdańsk: Gdańskie Wydawnictwo Psychologiczne.

Szumska, D. 2000. O emocjach bez emocji. w: Język a Kultura. Tom 14. Wrocław.

Szymanek, K. 2001. Sztuka argumentacji. Stownik terminologiczny. Warszawa: Wydawnictwo Naukowe PWN SA.

Tokarz, M. 2006. Argumentacja, Perswazja, Manipulacja. Wykłady z teorii komunikacji. Gdańsk: Gdańskie Wydawnictwo Psychologiczne. 
Tomalski, P. 2004. Cognitive Neuroscience: nic nie jest już proste. Kilka uwag o badaniach interakcji ciała i umysłu. w: J. Szymanik, M. Zajenkowski (red.), Kognitywistyka. O umyśle umyślnie i nieumyślnie. Warszawa: KFpM.

Totton, N. (ed.) 2005. New Dimensions in Body Psychotherapy. Maidenhead: Open University Press.

Totton, N. 2003. Body Psychotherapy. An Introduction. Maidenhead • Philadelphia: Open University Press.

Trenholm, S., Jensen, A. 1992. Poznanie społeczne: jak spostrzegamy jednostki, relacje i wydarzenia społeczne. w: Stewart, J. 2007. Mosty zamiast murów. Warszawa: Wydawnictwo Naukowe PWN.

Tyszka, T. 2000. Psychologiczne pułapki oceniania $i$ podejmowania decyzji. Gdańsk: Gdańskie Wydawnictwo Psychologiczne.

Ury, W. 2004. Odchodzac od NIE. Warszawa: Polskie Wydawnictwo Ekonomiczne.

Wendland, M. 2008. Komunikowanie a wymiana informacji - pytanie o zakres pojęcia komunikacji. w: Homo Communicativus. nr 4 (2004).

Wiener, D. 2006. Emocje - Systemy emocjonalne - Umyst. Próba kognitywnej charakterystyki procesów emocjonalnych. Praca doktorska napisana w Zakładzie Epistemologii i Kognitywistyki Instytutu Filozofii UAM w Poznaniu.

Wilson, M. 2002. Six Views of Embodied Cognition. w: Psychonomic Bulletin \& Review 2002, 9 (4), 625-636.

Wróbel, A. 2001. Czy można wierzyć zmysłom. w: Ohme, R.K., Jarymowicz, M., Reykowski, J. 2001. Automatyzmy $w$ procesach przetwarzania informacji. Warszawa: Wydawnictwo Instytutu Psychologii PAN Szkoła Wyższa Psychologii Społecznej.

Wróbel, M. 2005. Uwaga, zaraźliwy nastrój. w: Charaktery nr 8 (103), sierpień 2005.

Zajenkowski, M. 2004. Emocje i procesy poznawcze jako przykład elementarnych przedmiotów psychicznych. w: J. Szymanik, M. Zajenkowski (red.), Kognitywistyka. O umyśle umyślnie i nieumyślnie. Warszawa: KFpM.

Załazińska A., 2002, W poszukiwaniu narzędzia badającego komunikację niewerbalna, [w:] Język trzeciego tysiąclecia II, tom 1: Nowe oblicza komunikacji we wspótczesnej polszczyźnie, red. Szpila G., Kraków, s. 111.

Załazińska, A. 2006. Niewerbalna struktura dialogu. Kraków: Universitas.

Ziembiński, Z. 2000. Logika praktyczna. Warszawa: Wydawnictwo Naukowe PWN.

Żuk, M. 2001. O subiektywizmie w komunikowaniu się - refleksje językoznawcy i praktyka NLP. W: Język $w$ komunikacji, T.2 (s. 190-197). Łódź: Wydawnictwo WSHE. 